\title{
NATIONAL ENERGY STRATEGY: \\ RECENT STUDIES COMPARING THE HEALTH IMPACTS OF ENERGY TECHNOLOGIES
}

Michael D. Rowe

8

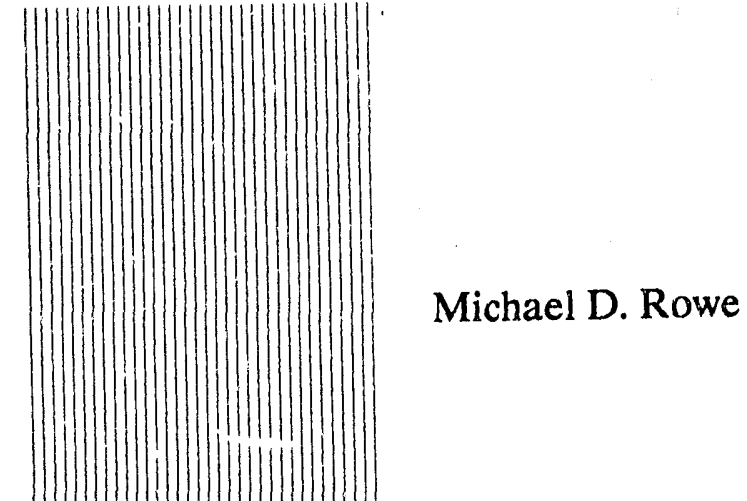

August 1990

\section{ANALYTICAL SCIENCES DIVISION DEPARTMENT OF APPLIED SCIENCE}

BROOKHAVEN NATIONAL LABORATORY UPTON, LONG ISLAND, NEW YORK 11973

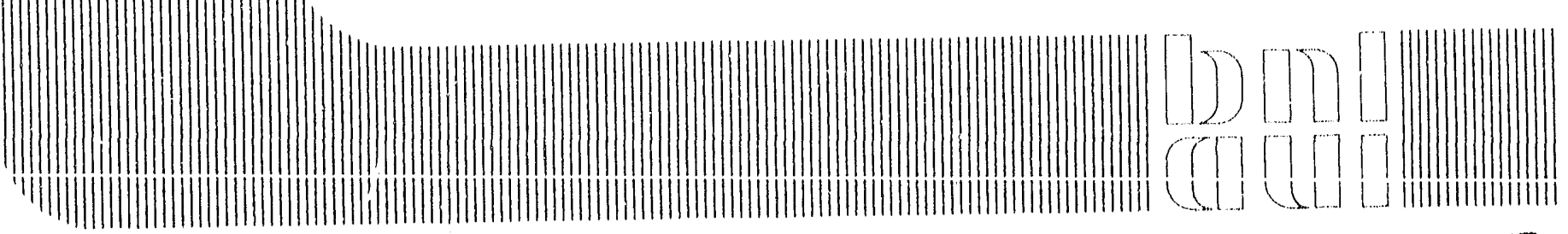


NATIONAL ENERGY STRATEGY:

RECENT STUDIES COMPARING THE HEALTH IMPACTS OF ENERGY TECHNOLOGIES

\author{
Michael D. Rowe
}

\title{
August 1990
}

\section{DISCLAIMER}

\begin{abstract}
This report was prepared as an account of work sponsored by an agency of the United States Government. Neither the United States Government nor any agency thereof, nor any of their employees, makes any warranty, express or implied, or assumes any legal liability or responsibility for the accuracy, completeness, or usefulness of any information, apparatus, product, or process disclosed, or represents that its use would not infringe privately owned rights. Reference herein to any specific commercial product, piocess, or service by trade name, trademark, manufacturer, or otherwise does not necessarily constitute or imply its endorsement, recommendation, or favoring by the United States Government or any agency thereof. The views and opinions of authors expressed herein do not necessarily state or reflect those of the United States Government or any agency thereof.
\end{abstract}

$$
\begin{aligned}
& \text { ANALYTICAL SCIENCES DIVISION } \\
& \text { DEPARTMENT OF APPLIED SCIENCE } \\
& \text { BROOKHAVEN NATIONAL LABORATORY } \\
& \text { ASSOCIATED UNIVERSITIES, INC. }
\end{aligned}
$$

Under Contract No. DE-AC02-76CH00016 with the U.S. Department of Energy 


\section{DISCLAIMER}

This report was prepared as an account of work sponsored by an agency of the United States Government. Neither the United States Government nor any agency thereof, nor any of their employees, not any of their contractors, sub- contractors, or their employees, makes any warranty, express or implied, or assumes any legal liability or responsibility for the accuracy, completeness, or usefulness of any information, apparatus, product, or process disclosed, or represents that its use would not infringe privately owned rights. Reference herein to any specific commercial product, process, or service by trade name, irademark, manufacturer, or otherwise, does not necessarily constitute or imply its endorsement, recommendation, or favoring by the United States Government or any agency, contractor, or subcontractor thereof. The views and opinions of authors expressed herein do not necessarily state or reflect those of the United States Government or any agency, contractor or subcontractor thereof. 


\section{ACKNOWLEDGMENTS}

This work was supported by the Environmental Analysis Division, Office of Policy and Analysis, U.S. Department of Energy, D. Moses, Project Manager. I thank S.C. Morris for review and helpful suggestions, and L.D. Hamilton for support and guidance. The report was completed by Janice DePass. 


\section{CONTENTS}

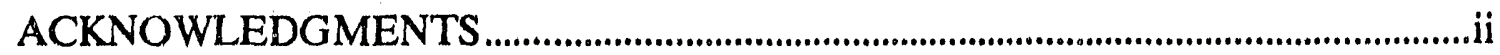

NATIONAL ENERGY STRATEGY:

RECENT STUDIES COMPARING THE HEALTH IMPACTS OF ENERGY

TECHNOLOGIES

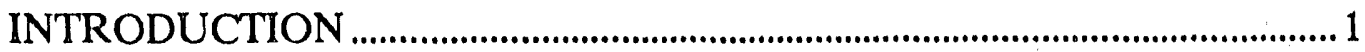

HEALTH RISK ASSESSMENT ...............................................................2

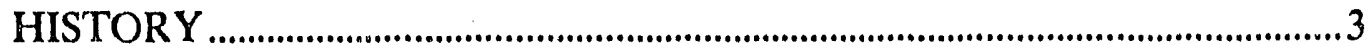

SUMMARY OF HEALTH EFFECTS ........................................................... 4

COMPARISON OF HEALTH EFFECTS....................................................

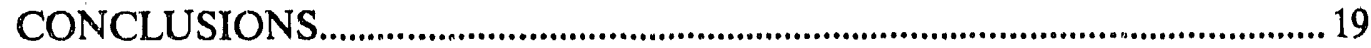

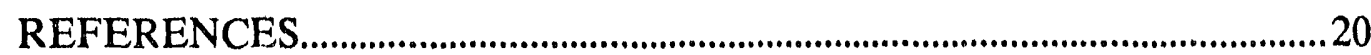




\section{NATIONAL, ENERGY STRATEGY: RECENT STUDIES COMPARING THE HEALTH IMPACTS OF ENERGY TECHNOLOGIES}

\section{INTRODUCTION}

The human health impacts of energy technologies arise mostly from routine emissions of . pollutants and from traumatic accidents, which may also release pollutants. The natures and magnitudes of the risks differ among technologies -- they are a lot different for some -and so the differences must be included in any evaluation of their relative merits.

Based on the characteristics of their health risks, energy technologies can be classified into three groups: ${ }^{1}$

o The Fuels Group is characterized by use of large amounts of fossil fuels or biomass -coal, oil, natural gas, wood, etc. -- the collection, processing, and transport of which have high accident rates that dominate occupational risks and the burning of which produces large amounts of air pollution and solid waste that dominate public risks.

- The Renewable Group is characterized by use of diffuse renewable resources with low energy density -- sun, wind, water -- which are available in enormous quantities at no cost, but the capturing of which requires large areas and construction of expensive facilities capable of "concentrating" ihem into useful forms. Occupational risks are high and dominated by construction of the facilities. Public risks are low, mostly confined to low-probability accidents, such as dam failures, equipment failures, and fires.

- The Nuclear Group includes nuclear fission technologies, which are distinguished by extremely high energy densities in the processed fuel, with correspondingly low quantities of fuel and wastes to process, but with low concentrations in the earth's crust, necessitating a large mining or collection effort. Occupational risks are, therefore, relatively high and dominated by mining and processing accidents. Public risks are small and dominated by routine operations of reactors. Special attention must be given to public fears of risks from exposure to radiation from nuclear technologies -- fears which are relatively large per unit risk to health.

Within these technology groups, health risks are similar in form and magnitude. But among the groups they are quite different. They occur in different parts of the fuel cycle, to different people, and their characteristics are different with respect to public perceptions of their relative importance in decision making. 
To compare the health risks of these different energy technologies on a common, rational basis, it is therefore necessary to consider entire fuel cycles, from their beginnings in extraction of fuels to their endings in disposal of wastes. Some analyses even include risks of providing materials for building and operating facilities.

It is also necessary to distinguish between effects on workers and on the general public, and between effects of routine operations and accidents. Hazards at work are normally accepted conditions of employment and are more or less controlled by safety regulations. Hazards to the general public are usually involuntary and poorly understood, often feared inordinately or ignored completely. Similarly, routine risks are subject to explicit or implicit acceptability criteria, but accidents are often too infrequent to be remembered and evaluated adequately. Frequent accidents (e.g., automobiles) soon become routine and accepted in the public mind; infrequent and severe accidents (ə.g., airplanes) are especially feared regardless of their likelihood.

We would also like to be able to distinguish between kinds of health effects -- acute and chronic, fatal and nonfatal, short-term and long-term sequela, etc. As is evident from public fears of radiation, all health risks are not equal. But because of problems with definitions and extensive overlapping in characteristics and severities among health effects of energy technologies, it is seldom possible to make such fine distinctions. Often studies include only risk of death for lack of other quantifiable endpoints for which useful data are available.

\section{HEALTH RISK ASSESSMENT}

A valid comparison of health risks of alternative energy technologies should include the following.

o Risks to workers.

- Routine exposure to chemicals, radiation, noise, and stress.

- Accidental trauma and exposure to chemicals, radiation, noise, and stress.

o Risks to the general population.

- Routine exposures.

Chemicals.

Radiation and electromagnetic fields.

Social factors (employment, population distribution, culture).

- Accidents.

Physical and chemical trauma.

Inhalation or ingestion of harmful chemicals.

Exposure to radiation. 
- Indirect risks from changes in the environment

Disease vectors

Food crops and nutrition

Livelihood and lifestyle

Important analytical considerations that should be addressed in a valid comparison of energy technologies are:

- Specification of technical boundaries of the system to be analyzed. Substitutability of technologies to be compared.

o Specification of geographic and time scales of interest. Discount rates into the future.

- Use of Mean estimates and/or confidence intervals. Content of confidence intervals.

o Use of consistent coefficients among alternatives for emissions, accidents, and health effects.

o Applicability of data from other countries.

o Analysis of routine and/or accidental effects. Severity of accidents included.

There are no studies that include all of these health risks for all or even a large number of energy technologies. Rather, there are studies of most of these risks from some technologies and some of these risks for most technologies. The best information is available on the things people care about most; the rest we must infer however we can. And there are no studies that are consistent with respect to all of the analytical considerations.

\section{HISTORY}

In the 1970's many governments and institutions expended large amounts of resources assessing the health and environmental impacts of alternative energy sources to provide data for long-term energy planning. This work generated a broad range of reports and comparisons, each attempting to improve on the previous. ${ }^{2}$ Since that time, however, work aimed at comparing alternative technologies has ceased. Work continues to characterize specific technologies, or even specific portions of technologies or stages of energy cycles, but we know of no ongoing work to put the new information together in a uniform way useful for intertechnology comparisons.

Most of the quantitative work available on the relative health impacts of energy technologies are, therefore, based on descriptions of technologies, environmental regulations and health effects information as they were 10 to 15 years ago, or on projections from that time of what they might look like in the future. 
But times and technologies have changed. Some new technologies are available or developing rapidly; some promising technologies failed to meet expectations.

Environmental controls have improved; attitudes have changed; regulations have become more stringent; new environmental concerns have developed. More studies of health effects of exposure to pollutants are available; in particular, it has become apparent that combustion products cannot be lumped together and treated the same for all technologies base on a single-pollutant (sulfur oxides) surrogate as we did in the past. ${ }^{3}$

This discussion, therefore, places limited emphasis on the details and magnitudes of the available estimates of health effects of energy technologies. We would get slightly different numbers were we to repeat the studies today. But the available data remain useful for comparisons among technologies, particularly for comparisons among the technology groups described above. The health effects of these groups are so different, and occur in such different places and to different people, that the small technology- and pollutantspecific details are of less importance.

\section{SUMMARY OF HEALTH EFFECTS}

The significant health effects of technologies for generating electricity are shown in Tables 1 through 3.

\section{COMPARISON OF HEALTH EFFECTS}

1970 's. Paskievici reviewed 15 important studies from the active period of the 1970 's. ${ }^{4}$ Some of these studies have been heavily criticized in the literature for methodological inadequacies and all are exceedingly inbred, one building on the results anciassumptions of another (Figure 1). Yet their results vary by as much as a factor of 100 even for the same author in different studies. The numbers reported by Paskievici are also subject to heavy criticism because of exceedingly low quality control during extraction and conversion to standard units. ${ }^{5}$ Appendices A-1 through A-8 show results from Paskievici's survey as partially recalculated and corrected by Brookhaven National Laboratory. ${ }^{6}$ Given that the verification of Paskievici's results is incomplete, the primary usefulness of these numbers is to illustrate the exceedingly high uncertainty of such derivations. 


\begin{tabular}{|c|c|c|}
\hline Technology & Occupational Health effects & Public \\
\hline Coal & $\begin{array}{l}\text { Black lung disease } \\
\text { Trauma from mining accidents } \\
\text { Trauma from transport accidents }\end{array}$ & $\begin{array}{l}\text { Air pollution health effects } \\
\text { Trauma from transport accidents }\end{array}$ \\
\hline Oil & $\begin{array}{l}\text { Trauma from drilling accidents } \\
\text { Cancer from exposure :o refinery } \\
\text { organics }\end{array}$ & $\begin{array}{l}\text { Air pollution health effects } \\
\text { Trauma from explosions and fires }\end{array}$ \\
\hline Oil shale & $\begin{array}{l}\text { Brown lung disease } \\
\text { Cancer from exposure to retorting } \\
\text { emissions } \\
\text { Trauma from mining accidents }\end{array}$ & $\begin{array}{l}\text { Cancer from exposure to } \\
\text { retorting } \\
\text { emissions } \\
\text { Air pollution health effects }\end{array}$ \\
\hline Natural gas & $\begin{array}{l}\text { Trauma from drilling accidents } \\
\text { Cancer from exposure to refinery } \\
\text { emissions }\end{array}$ & $\begin{array}{l}\text { Air pollution health effects } \\
\text { Trauma from explosions and fires }\end{array}$ \\
\hline Tar sands & Trauma from mining accidents & $\begin{array}{l}\text { Air pollution health effects } \\
\text { Trauma from explosions and fires }\end{array}$ \\
\hline Biomass & $\begin{array}{l}\text { Trauma from accidents during } \\
\text { gathering and processing } \\
\text { Exposure to hazardous chemicals } \\
\text { and biological agents from } \\
\text { processing and conversion }\end{array}$ & $\begin{array}{l}\text { Air pollution health effects } \\
\text { Diseases from exposure to } \\
\text { pathogens } \\
\text { Trauma from house fires }\end{array}$ \\
\hline $\begin{array}{l}\text { a. Source } \\
\text { Enviro } \\
\text { Intern }\end{array}$ & $\begin{array}{l}\text { lton, L.D. Presentation to the } I \\
\text { I and Heaith Impacts from Diffe } \\
\text { Atomic Energy Agency, Vienna, }\end{array}$ & $\begin{array}{l}\text { Advisory Group on Comparative } \\
\text { Energy Sources. March 5-9, } 1990 \\
\text { ia. }\end{array}$ \\
\hline
\end{tabular}




\begin{tabular}{|c|c|c|}
\hline Technology & Occupational & Public \\
\hline Geothermal & $\begin{array}{l}\text { Exposure to toxic gases -- } \\
\text { routine and accidental } \\
\text { Stress from noise } \\
\text { Trauma from drilling accidents }\end{array}$ & $\begin{array}{l}\text { Disease from exposure to toxic } \\
\text { brines and hydrogen sulfide. } \\
\text { Cancer from exposure to radon }\end{array}$ \\
\hline $\begin{array}{l}\text { Hydropower, } \\
\text { conventional } \\
\text { and low-head }\end{array}$ & Trauma from dam failures & $\begin{array}{l}\text { Trauma from construction } \\
\text { accidents } \\
\text { Disease from exposure to } \\
\text { pathogens }\end{array}$ \\
\hline Photovoltaics & $\begin{array}{l}\text { Exposure to toxic materials } \\
\text { during fabrication -- routine } \\
\text { and accidental }\end{array}$ & $\begin{array}{l}\text { Exposure to toxic materials } \\
\text { during fabrication and disposal } \\
\text {-- routine and accidental }\end{array}$ \\
\hline Wind & $\begin{array}{l}\text { Trauma from accidents during } \\
\text { construction and operation }\end{array}$ & \\
\hline Solar thermal & $\begin{array}{l}\text { Trauma from accidents during } \\
\text { fabrication } \\
\text { Exposure to toxic chemicals during } \\
\text { operation }\end{array}$ & \\
\hline \multicolumn{3}{|c|}{$\begin{array}{l}\text { a. Source: Hamilton, L.D. Presentation to the IAEA Advisory Group on Comparative } \\
\text { Environmental and Health Impacts from Different Energy Sources. March 5-9, } 1990 \\
\text { International Atomic Energy Agency, Vienna, Austria. }\end{array}$} \\
\hline
\end{tabular}


Table 3, Significant health effects of technologies for generating electricity -- Nuclear Group. ${ }^{\mathrm{a}}$

$\begin{array}{lll}\text { Technology Health effects } & \text { Public }\end{array}$

Fission Cancer from exposure to radiation during uranium mining, ore/fuel processing, power plant operation and waste management

Cancer from exposure to radiation during all stages of the fuel cycle -.. routine and accidental

Trauma from industrial accidents during mining, processing, power

Trauma from transport accidents plant construction and operation, and waste management

a. Source: Hamilton, L.D. Presentation to the IAEA Advisory Group on Comparative Environmental and Health Impacts from Different Energy Sources. March 5-9, 1990 International Atomic Energy Agency, Vienna, Austria.

With respect to the uncertainty of the estimates, Paskievici concluded:

o Differences in dose-effect model can produce variations of a factor of 100 ;

- Differences in postulated antipollution equipment can produce variations of a factor of 25 ;

o Differences in location of the facility can produce variations of a factor of 10.

o Differences in the distances over which exposures are estimated (e.g., $<50 \mathrm{mi},>50$ $\mathrm{mi}$ ) can produce variations of a factor of 10 ;

- The nuclear fuel cycle is better understood and better quantified that the other fuel cycles; and

o Much of the variability in these estimates reflects our limited knowledge of the physical, chemical, and biological reactions that connect emissions of pollutants to health effects;

Readers should not place a great deal of weight on the ranges included in the various tables herein. They are not derived from a consistent basis, but rather represent those portions of the total uncertainty the analysts were unable or unwilling to include in the analyses. In some cases they represent the range of other analysts' estimates, which depend a great deal on their assumptions. Although some assumptions are becoming "standardized" by default from repeated use, there are few rules that assure consistency. Often the ranges include only one or two variables for which the analysts were unable to specify a "best estimate" on some rational basis. 


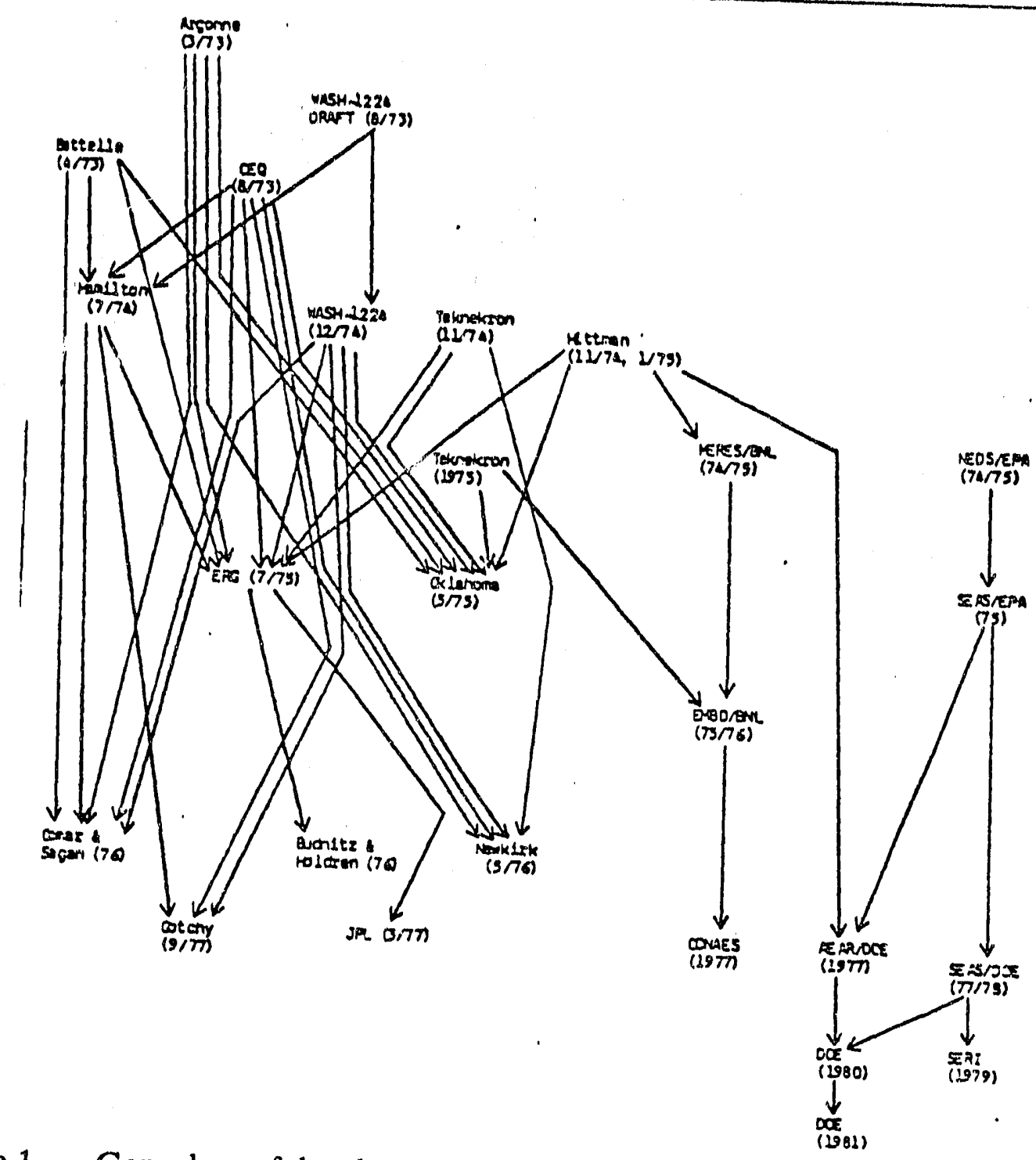

Figure 1. Genealogy of data bases comparing health and safety of energy technologies. (Source: OECD. Environmental Effects of Energy Systems. The OECD France. April 1983.)

This is not necessarily bad with respect to the usefulness of the results for policy analysis and decision making. Were all of the sources of uncertainty contained in an estimated included, the range of the result would be so large as to be essentially meaningless and therefore useless. It is better to constrain the estimate to a specified set of circumstances that are easy to understand than to include all circumstances and produce a result that is not understandable. Differences between what is analyzed and the real world can be dealt with intuitively. Therefore, consistency is more important than completeness. 
The health risk estimates are, therefore, much more uncertain than is indicated by their ranges along. How much more uncertain can be seen from Paskievici's comparison. Paskievici separated diseases from normal operations from effects of accidents, diseases and trauma. He selected his "best estimate" of the risks of diseases from normal operations based on his review (Table 4); "best" appears to be mostly subjective judgment. From these he concluded the following.

- The total risk of occupational diseases is negligible for the oil and natural gas fuel cycles and similar for the coal and uranium fuel cycles. Major risks of occupational diseases in the coal cycle occur during extraction; those in the uranium cycle occur at power plants and reprocessing facilities.

- The risk of fatalities in the general population is negligible for the natural gas cycle, relatively low for the uranium cycle, and relatively high for the coal and oil cycles.

o The risk of fatalities in the general population is lower than that of occupational fatalities for the uranium cycle, but higher for the coal and oil cycles.

o The risk of occupational diseases is negligible in the natural gas cycle, and higher in the oil, uranium, and coal cycles, in that order.

- The total risk of non-fatal diseases is much higher for the coal and oil cycles than for the uranium cycle; the natural gas cycle has practically no health effects.

Paskievici also selected subjective "best estimates" for health risks of accidents (Table 5). These include only statistics on real accidents, not hypothetical ones, anc in mnst cases $\mathrm{d} r$ riot include accidents during construction and dismantling of facilities. No public risks from nuclear accidents are inicluded, as there were no data from real accidents when the report was written. He concluded the following.

o Estimates of health risks of accidents are less uncertain than those of routine operations. Results of different studies agree within a factor of 2. Differences are attributable to assumptions about working conditions and interpretations of statistical data. 
Table 4. "Best estimates" of health effects of fuel cycles, not including accidents, Paskievici, 1980. ${ }^{\mathrm{a}}$

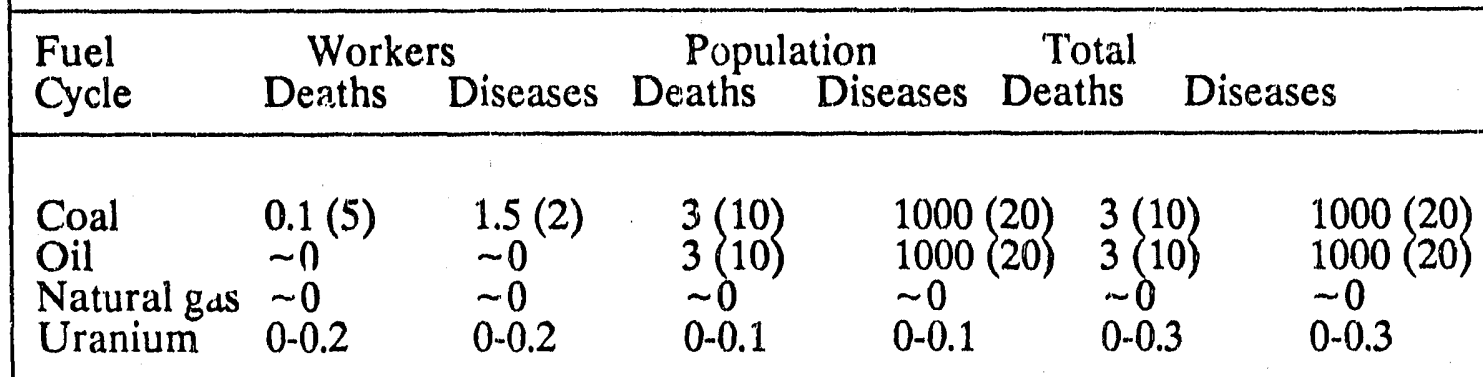

a. Estimated uncertainty factors are given in parentheses.

Table 5. "Best estimates" of health effects of accidents in fuel cycles, Paskievici, 1980. ${ }^{\mathrm{a}}$

\begin{tabular}{|c|c|c|c|c|c|c|}
\hline \multirow{2}{*}{$\begin{array}{l}\text { Fuel } \\
\text { Cycle }\end{array}$} & \multirow{2}{*}{$\begin{array}{l}\text { Workers } \\
\text { Fatal }\end{array}$} & \multicolumn{2}{|c|}{ Population } & \multicolumn{2}{|l|}{ Total } & \multirow[b]{2}{*}{ Non-fatal } \\
\hline & & Non-fatal & Fatal & Non-fatal & Fatal & \\
\hline Coal & $1.40(1.5)$ & $60(1.5)$ & $1.0(1.5)$ & $1.8(2.0)$ & $2.4(1.5)$ & $62(1.5)$ \\
\hline & $0.35(1.5)$ & $30(1.5)$ & & & $0.35(1.5)$ & $30(1.5)$ \\
\hline Natural gas & $0.20(1.5)$ & $15(2)$ & $0.009(1.5)$ & $0.005(1.5)$ & $0.21(1.5)$ & $15(2)$ \\
\hline Uranium & $0.20(1.5)$ & $15(2)$ & $0.012(1.5)$ & $0.11(2)$ & $0.21(1.5)$ & $15(2)$ \\
\hline
\end{tabular}

a. Estimated uncertainty factors are given in parentheses.

- The risks of occupational fatalities in the natural gas and uranium cycles are very small; those for the oil and coal cycles are two and seven times larger, respectively. The risks in the coal cycle are mostly from mining; those from the nuclear cycle are more evenly distributed.

o The risk of fatalities in the general population from accidents is essentially negligible for the oil, natural gas, and uranium cycles. It is about 100 times greater for the coal cycle. In all cases, public risk arises from transport of fuel.

o The risks of occupational injuries h.uve the same distribution as occupational fatalities -- lowest for the natural gas and uraniurn cycles, two times higher for oil, and four times higher for coal.

o The risk of injuries in the general population is very low, with the coal cycle being an order of magnitude higher than the natural gas and uranium cycles.

1980 's. We know of only three large integrated studies done in the 1980's that attempt to compare energy technologies on a uniform, consistent basis for complete fuel cycles, one by the United Nations Environment Program, ${ }^{7}$ another done specifically for conditions in 
Switzerland, ${ }^{8}$ and one by the Electric Power Rescarch Institute which includes mostly occupational health risks. ${ }^{9}$ In spite of their more recent publication dates, however, most of the data used was taken from the earlier studies from the 1970's, and at best only a few technologies have been updated to account for changes in conditions.

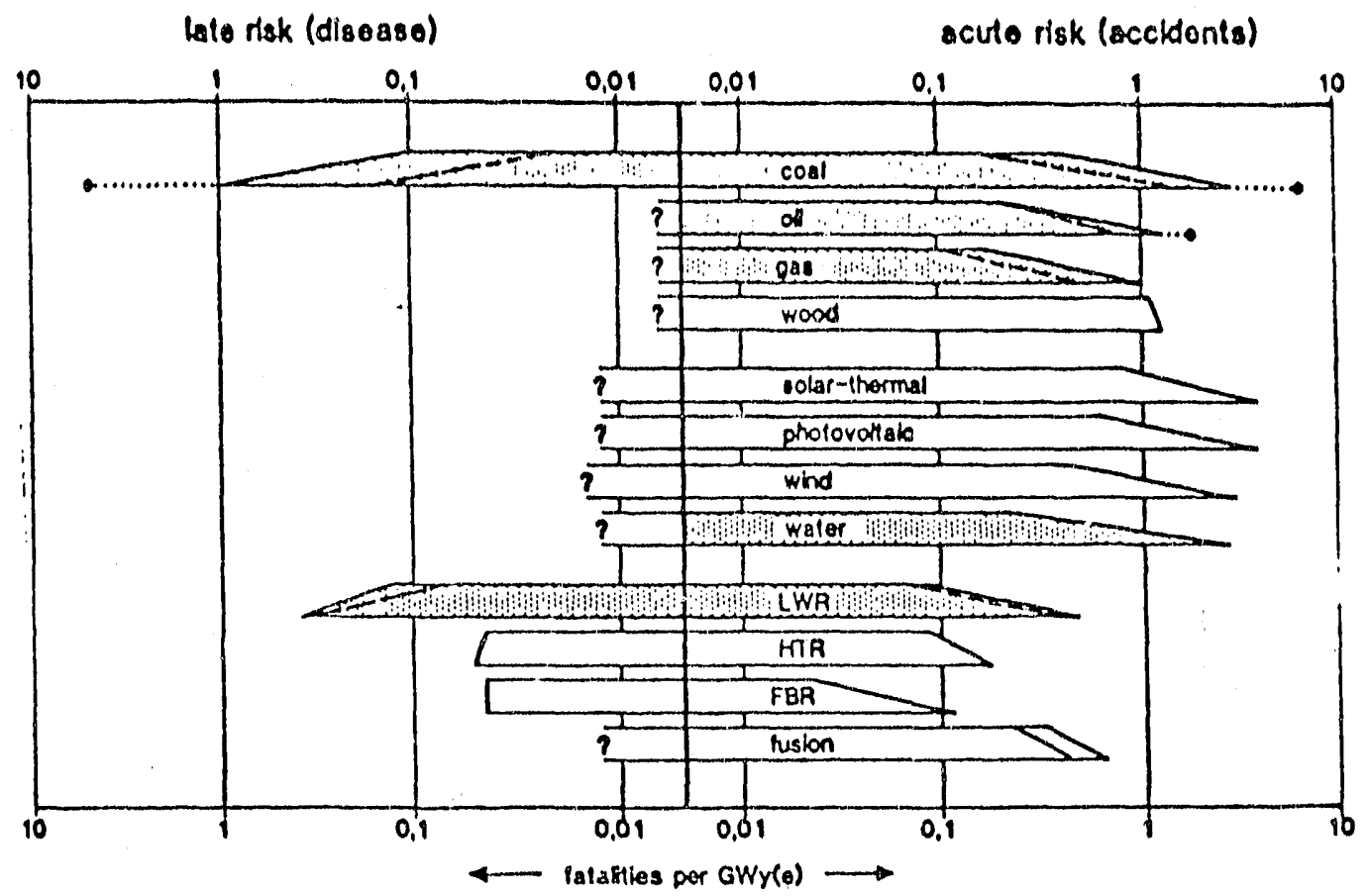

Figure 2. Occupational mortality risks of energy production from all stages of the fuel cycle, without severe accidents. (Source. Fritzsche 1989.)

Fritzsche. The most recent comparison is by Fritzsche for alternative energy systems in Switzerland. ${ }^{10}$ Fritzsche critically reviewed the literature on comparative risk assessments for energy technologies, with emphasis on more recent studies, and renormalized the results to represent conditions in Switzerland and the Federal Republic of Germany with respect to pollution emissions, population density, and the environment. He considers that the results are representative of new large modern power plants that could be built now in Europe. Note that the origin of these estimates is a report written in German, and we have not had an opportunity to evaluate its quality. There are suggestions that the assumptions and methods used may not be standard (e.g. high public risks from chronic diseases in the Renewable Group [Fig. 3])

Figures 2 and 3 show Fritzsche's results for acute and chronic health effects to workers and the public for routine operations and accidents. The sloping ends of the bars represent the range of the estimates; the dotted shading indicates results of higher quality for wellstudied systems. The scale is logarithmic, which tends to de-emplasize differences among technologies. 
Figures 4 and 5 slow Fritzsche's summary of results for severe accidents (more than 10 simultaneous deaths) world-wide (Table 6), which he assesses scparately because of special public concern.

Fritzsche concludes that the health risks of production of electricity are relatively well know, even with respect to the probability of unlikely but potentially serious accidents. The technologies of the Fuels Group generally have high routine risks to the persons who collect the fuel and, except for matural gas, high routine risks to the public from inhalation of combustion products. The technologies of the Renewables Group have high routine risk to workers from construction of facilities, and "nonnegligible" routine risks to the public. The technologies of the Nuclear Group have "nonnegligible" routine risks to miners and operators of facilities and very low routine risks to the public.

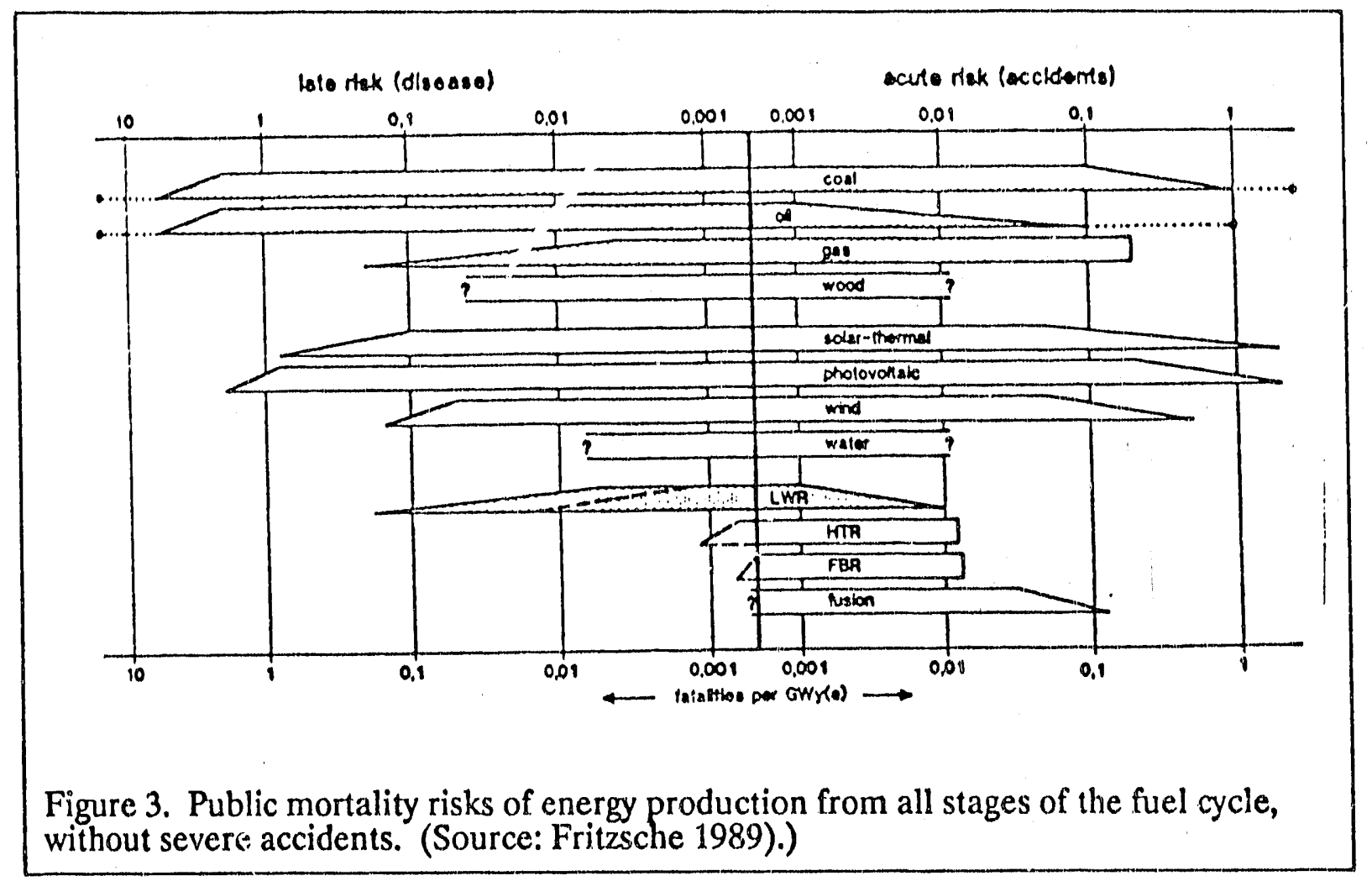

Fritzsche also concludes that the probability of a severe accident is relatively high for the Fuels Group, low for the Nuclear Group, and, except for dam failures, essentially inconceivable for the Renewables Group.

UNEP. The second study was a massive, multi-year effort by the United Nations Environmental Program that attempted to incorporate and generalize essentially all of the quantitative health and environmental risk information available in the literature at that time. ${ }^{11}$ Any effort of such size and scope is inevitably vulnerable to criticism for 
inconsistencies and procedural inadequacies that make the results highly uncertain. Nevertheless, this study is the largest, most complete, and most recent of those available. Virtually all of the results of this study are summaries of those from the reports of the 1970 's.

Results from the United Nations Environment Program project are shown in Appendix B1. Since the entire fuel cycle is not includeed for all technologies, the estimates of health risks are not completely comparable in every case.

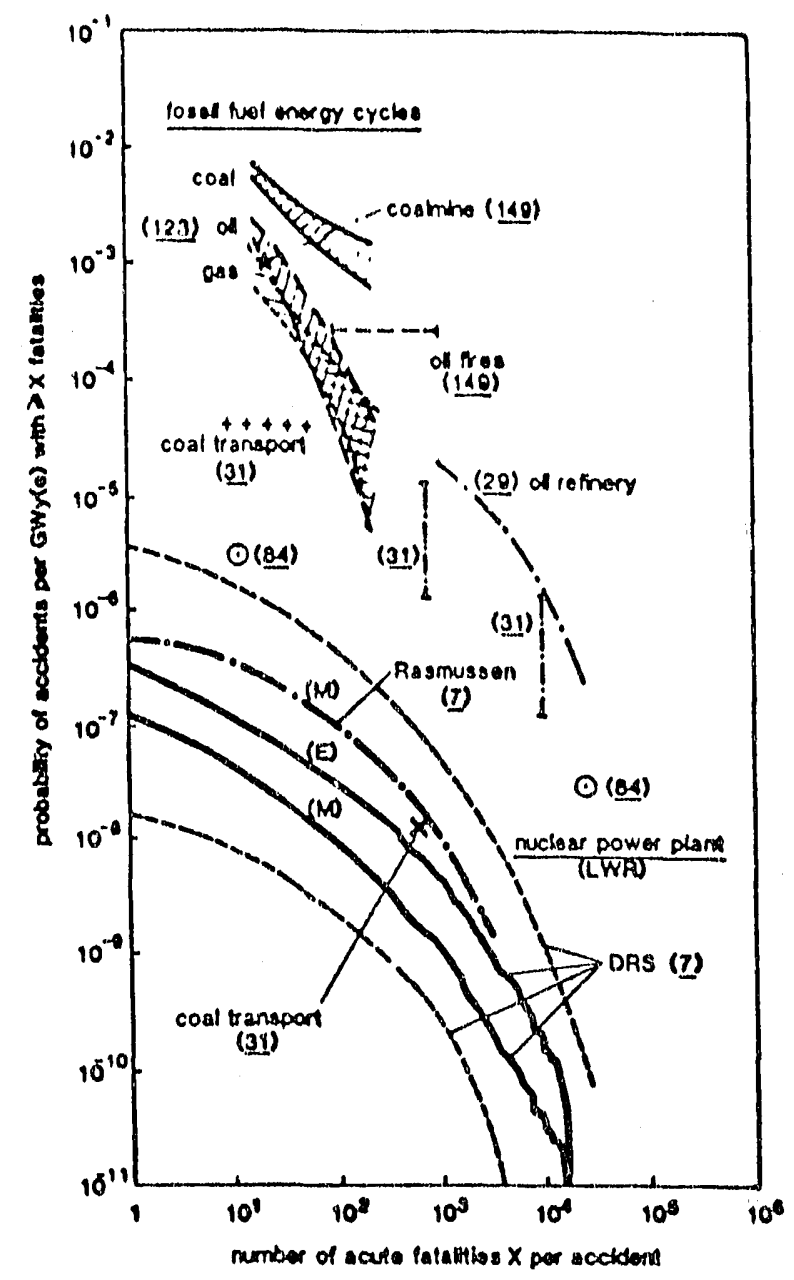

Figure 4. Frequency of acute fatalities per GWe-y electricity production from severe accidents in the nuclear and fossil-fuel systems. (Source: Fritzsche 1989).) 


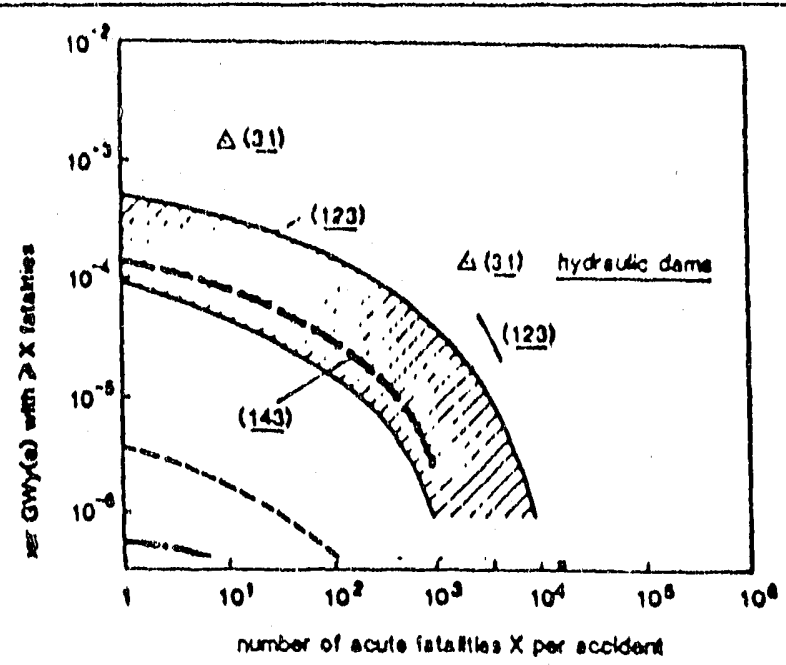

Figure 5. Frequency of acute fatalities per GWe-y electricity production from severe accidents in hydraulic dams. (Source: Fritzsche 1989.)

Table 6. Severe accidents world-wide in the period 1969 to $1986 .^{\mathrm{a}}$

\begin{tabular}{|c|c|c|c|c|c|}
\hline $\begin{array}{l}\text { Energy } \\
\text { option }\end{array}$ & $\begin{array}{c}\text { No. } \\
\text { Severe } \\
\text { accidents }\end{array}$ & Cause & Stage & $\begin{array}{c}\text { Acute fatalities } \\
\text { per } \\
\text { event }\end{array}$ & $\begin{array}{l}\text { Average } \\
\text { per year }\end{array}$ \\
\hline Coal & 62 & $\begin{array}{l}\text { Mine } \\
\text { accident }\end{array}$ & $\begin{array}{l}\text { Coal } \\
\text { mine }\end{array}$ & $10-434$ & $>200$ \\
\hline \multirow[t]{3}{*}{ Oil } & 6 & Capsizing & Oil & $6-123$ & \\
\hline & 15 & $\begin{array}{l}\text { Fire/ } \\
\text { explosion }\end{array}$ & $\begin{array}{l}\text { Refineries, } \\
\text { tank farms }\end{array}$ & $5-145$ & $\sim 25$ \\
\hline & 42 & $\begin{array}{l}\text { Fire/ } \\
\text { explosion }\end{array}$ & Transport & $5-500$ & $>90$ \\
\hline $\begin{array}{l}\text { Natural } \\
\text { gas }\end{array}$ & 24 & $\begin{array}{l}\text { Fire/ } \\
\text { explosion }\end{array}$ & Various & $6-452$ & $>80$ \\
\hline Water & $>8$ & Over-topping & Dams & $11-2500$ & $>200$ \\
\hline Nuclear & 1 & Meltdown & Chernobyl & 31 & \\
\hline
\end{tabular}

Figures 6 and 7 show total occupational fatalities for electricity and large-scale heating fuel cycles. The highest occupational risks are associated with technologies involving much intermediate processing (coal gasification, coal liquefaction, oil shale). Direct combustion 
of fuels has lower occupational risk (excepting natural gas), with the specific level of risk being related to the energy density of the fuel. High-technology systems (nuclear, renewables) plus natural gas have the lowest occupational risks. The ratios of deaths to injuries are not constant among technologies.

EPRI. The study by EPRI reviews important past studies that assesses methodologies and presents a state-of-the-art general "risk accounting" methodology for health risk assessment, which was applied to a comparative risk assessment of eight energy systems for generating electricity. This reprort provides considerable detail on basic methodologies and their limitations for inter-technology comparisons.

- Risk levels of alternative technologies are not fixed, but are functions of the resources expended to reduce them. Allocation of resources is a policy decision.

o Even though estimates of occupational health risks are easiest to obtain and have the best quality of supporting data, the range of plausible results is nevertheless orders of magnitude. This range is an inevitable result of the level of disaggregation of the data from which the basic calculations are made, and of ambiguities in specifications of processes. We cannot expect to do better with currently availiable data.

Results from the EPRI study are summarized in Figure 8 and Table 7. The study concludes the following.

- Results for different technologies should not be compared unless they are directly substitutable one for another (e.g., a peaking plant should not be compared with a base-load plant).

- Public health risks are more difficult to estimate than occupational risks. Risks from pollution emissions are particularly difficult to quantify. Some useful results are available for specific plants; results for "generic" technologies are probably not useful.

- Two particularly important methodological gaps are highlighted.

- The more precise is the definition of a technology, the better the quality of the results, but the less general are the conclusions that can be made from them.

- When there are "risk externalities" arising from multiple plants or end uses, joint production, or combined emissions, it is not clear how the share of the total risk -- the attributable risk -- should be estimated. 


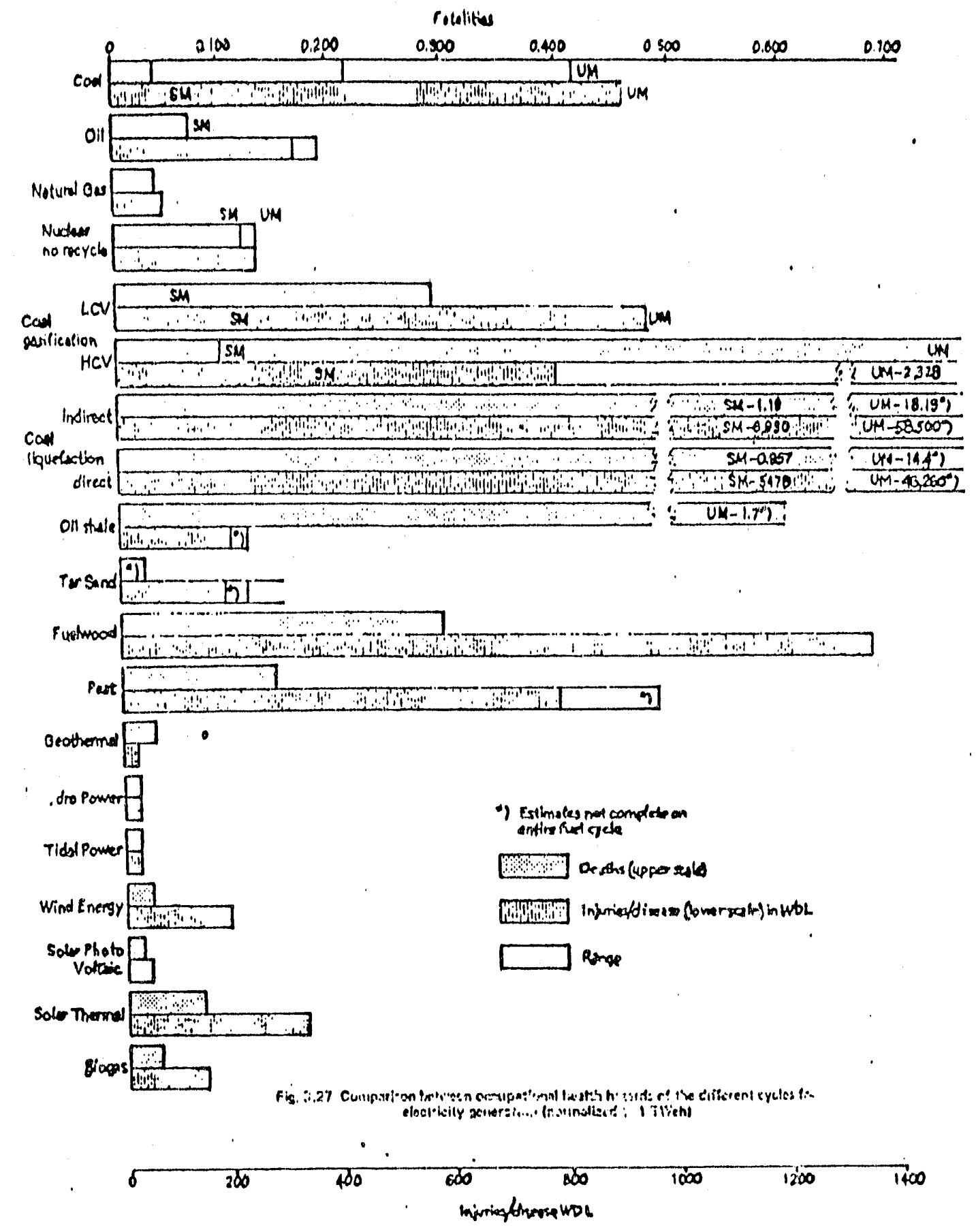

Figure 6. Occupational health risks of different energy cycles for generating electricity. (Source: UNEP 1985.) 


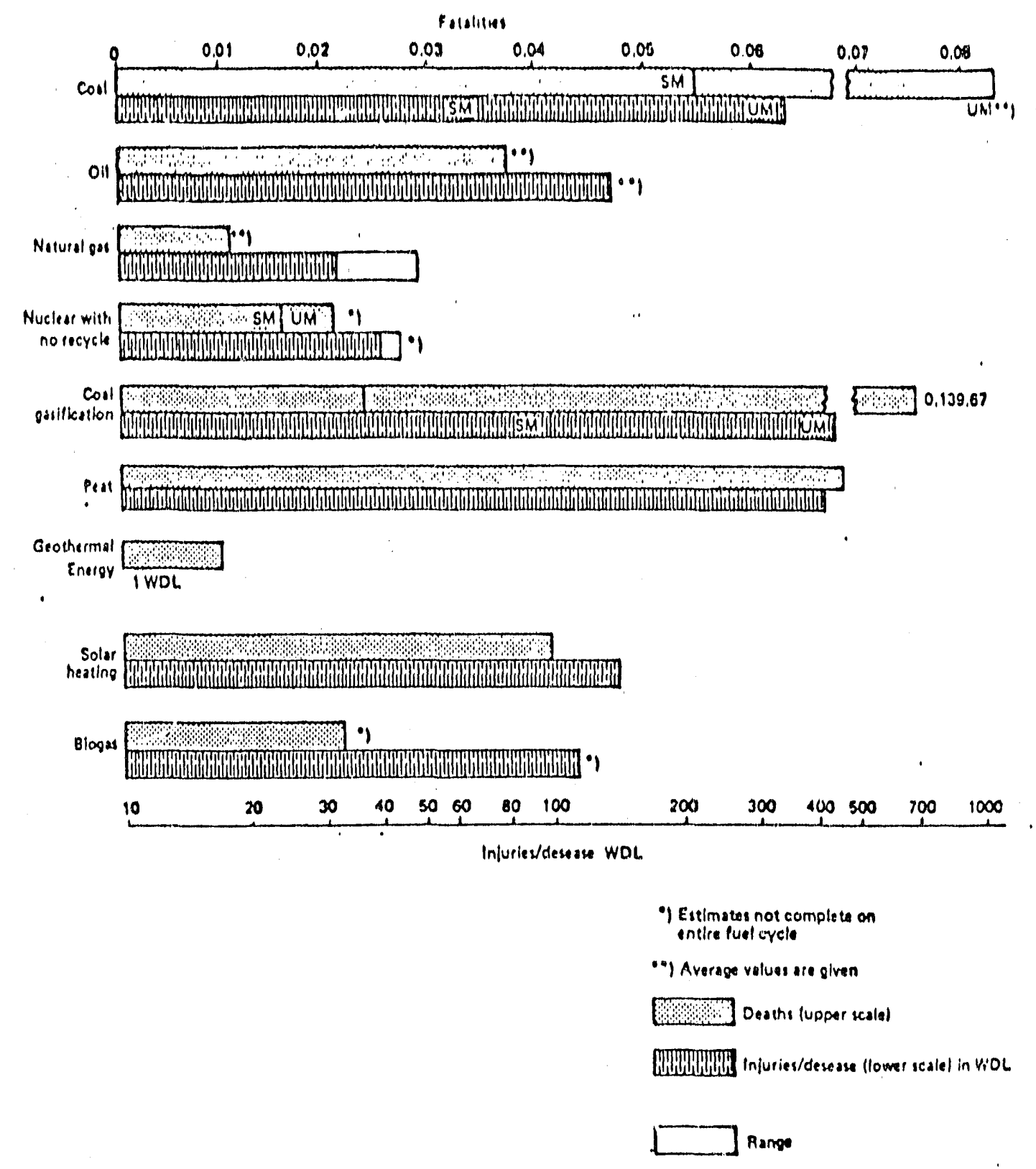

Figure 7. Occupational health risks of different energy cycles for large-scale generaticn of heat. (Source: UNEP 1985.) 


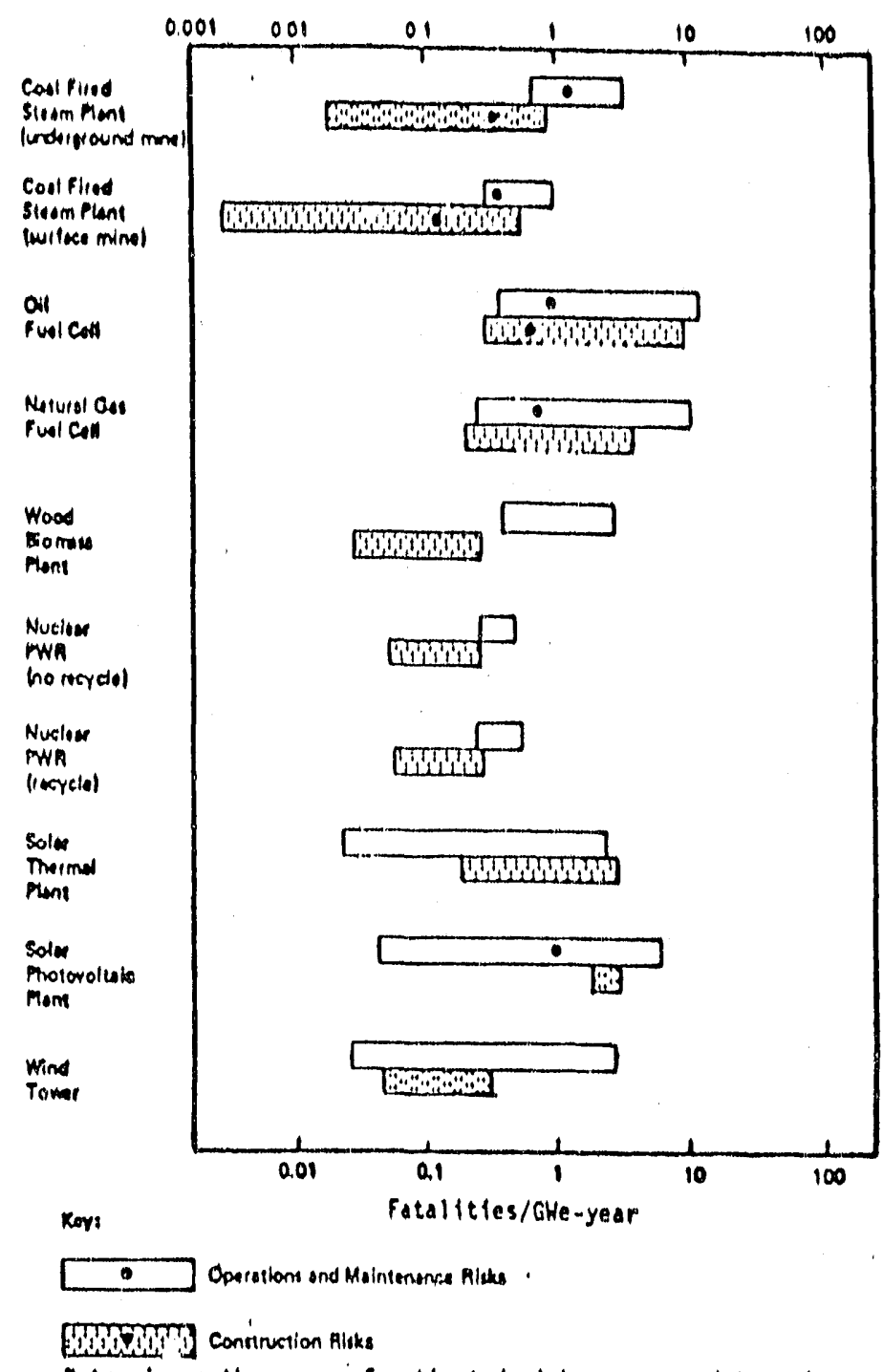

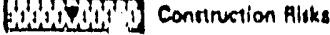

Dots w? in the range of estlmated risk correspond to point estimates whert, uch estimates have been made.

Cautionary Note: Comparison of risks between technologies cannot be made meaningfully unless the technologies are substitutable.

Figure 8. Expected range of occupational fatalities per GWe-y from construction, operation, and maintenance of energy facilities. (Source: EPRI 1985.) 


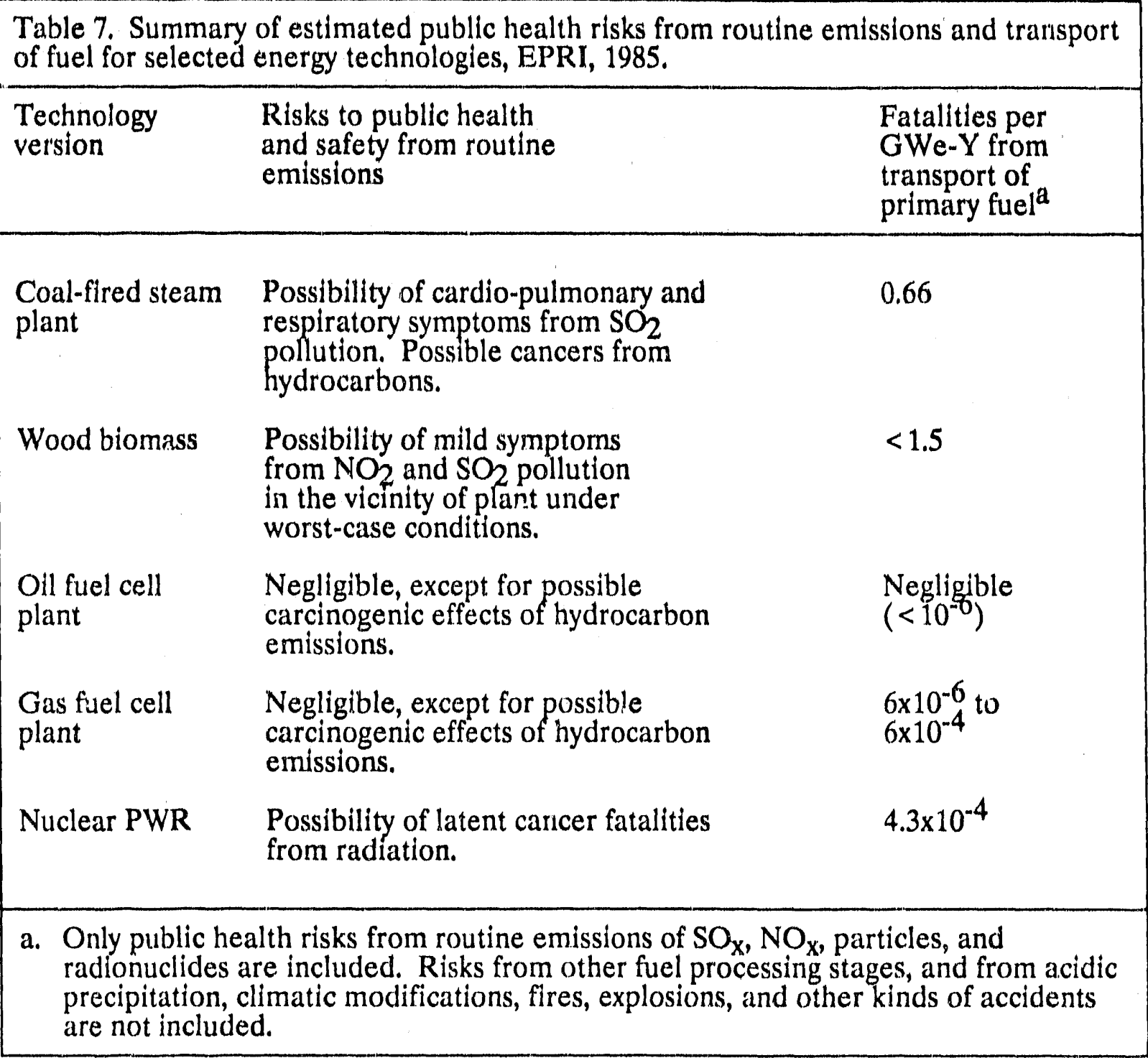

\section{CONCLUSIONS}

The literature contains quantitative estimates of occupational and public health risks of energy technologies that can form a general basis for policy analysis and decision making. These results are technically slightly out of date, but not by so much as to be no longer useful.

The results indicate that the risks of different technologies are different, often significantly so with respect to the bearers of the risk. But taken as a whole, for entire fuel cycles and energy systems, the differences among alternatives are not especially large compared to the uncertainty of the estimates. 
The quality of the available information is inadequate to support detailed, quantitative, resource optimization studies based on estimated levels of health impacts. Instead, it can be used to provide general insights and some confidence that whatever energy technologies are selected for other reasons, there are not likely to be any future surprises with respect to the actual health risks of providing energy. Risks that seem unacceptably high based on these estimates can be studied in more depth and resources can be allocated to reducing them if it seems appropriate.

\section{REFERENCES}

1 Fritzsche, A.F. The health risks of energy production. Risk Analysis 9:565-577 (1989).

2 See the reports reviewed by W. Paskievici, Health Hazards Associated with Electric Power Production: A comparative Study. Presented at the 4th Annual Meeting of the International Scientific Forum on Geopolitics of Energy, Fort Lauderdale, FL, November 10-14, 1980.

3 Fischer, H., L.D. Hamilton, S.C. Morris, P.D. Moskowitz, J. Nagy, and M.D. Rowe. Health Effects of Conventional Energy sources: A Health and Environmental Effects Document. Brookhaven National Laboratory, Upon, NY. September, 1983.

4 Paskievici, W. Health Hazards Associated with Electric Power Production: A comparative Study. Presented at the 4th Annual Meeting of the International Scientific Forum on Geopolitics of Energy, Fort Lauderdale, FL, November 10-14, 1980. Paskievici reviewed the following reports:

U.S. Atomic Energy Commission. Comparative Risk-Cost-Benefit Study of Alternative Sources of Electrical Energy: A Compilation of Normalized Cost and Impact Data for Current Types of Power Plants and their Supporting Fuel Cycles. WASH-1224, 1974.

Hamilton, L.D. The Health and Environmental Effects of Electricity Generation -- A Preliminary Report. BNL-20582. Brookhaven National Laboratory, Upton, NY, 1974.

Hittman Associates, Inc. Environmental Impacts, Efficiency and Cost of Energy Supply and End Use, NTIS Report No. PB-239. Prepared for the National Science Foundation, the Environmental Protections Agency, and the Council on Environmental Quality, 1974.

Smith, K.R., et al. Evaluation of conventional Power Systems. ERG 75-7. University of California, 1975

Comar, C.L.. and L.A. Sagan. "Health effects of energy production and conversion." Annual Review of Energy, 1:581-600 (1976). 
Pochin, E.E. Estimated Population Exposure from Nuclear Power Production and Other Radiation Sources, Nuclear Energy Agency, Organization for Economic Co-operation and Development, Paris, France, 1976.

MITRE Corp. Accidents and Unscheduled Events Associated with Non-nuclear Energy Resources and Technology, NTIS Report PB-265-398. Prepared for the U.S. Environmental Protection Agency, Washington, DC, 1977.

Morris, S.C. Comparative Effects of Coal and Nuclear Fuel on Mortality, BNL-23579. Brookhaven national Laboratory, Upton, NY, 1977.

WHO Health Implications of Nuclear Power Production, Report of a Working Group. World Health Organization regional Office for Europe, Copenhagen, 1978

Inhaber, H. Risk of Energy Production, AECB-1149 revised. Atomic Energy control Board, Ottawa, Canada, 1978.

Institute for Energy Analysis, ORAD. Economic and Environmental Impacts of a U.S. Nuclear Moratorium, 1985-2000, The MIT Press, Boston, 1979.

AMA Council on Scientific Affairs. "Health evaluation of energy-generating sources." J. Amer. Med, Assoc. 240:2193-2195 (1978).

U.K. Health and Safety Commission. The Hazards of Conventional Sources of Energy. Her Majesty's Stationary Office, London, England, 1978.

Ramsay, W. Unpaid costs of Electrical Energy: Health and Environmental Impacts from Coal and Nuclear Power. John Hopkins University Press, Baltimore, MD, 1978.

Schurr, S.H., et al. Energy in America's Future. The Choices Before Us, Resources for the Future National Energy Strategies Project. Johns Hopkins University Press, Baltimore, MD, 1979.

Morris, S.C., K.M. Novak, and L.D. Hamilton. Databook for the Quantitation of Health Effects from Coal Energy Systems (Draft), Brookhaven National Laboratory, Upton, NY, 1979.

Inhaber, H. Risk of Energy Production. AECB/REV-3. Atomic Energy Control Board, Ottawa, 1980.

Belhoste, J.F., B. Durant, and C. Maccia. Risques Sanitaires et Écologiques de la Production d'Énergie Electrique. Cycle Nucléaire (PWR), Fuel, Charbon. Présentation Des Scénarios, Centre d'études sur l'évaluation de la protection dans le domaine Nucléaire, Fontenay-aux-Roses, France, 1979.

Committee on Nuclear and Alternative Energy systems (CONAES). Alternative Energy Demand Futures, U.S. National Academy of Sciences, 1980.

Hamilton, L.D. Personal communication. Brookhaven National Laboratory Upton, NY. August 29, 1990. 
BEAD. Unpublished analysis and correction of Paskievici's results. Brookhaven National Laboratory Upton, NY. August, 1982.

7 UNEP. The Environmental Impacts of Production and Use of Energy. Part IV: The Comparative Assessment of the Environmental Impacts of Energy Sources (3rd Draft). United Nations Environment Program, Nairobi, Kenya. January 1985.

8 Fritzsche, A.F. Gesundheitsrisiken von Energieversorgungs-systemen. Von der Kohle bis zu Energien der Zukunft und den Rohstoffen bis zur Entsorgung, Verlag TÜV Rheinland, Köln. 1988 (in German).

9 Cox, L.A., Jr., J. Fiksel, and A.S. Kalelkar. Analysis of Routine Occupational Risks Associated with Selected Electrical Energy Systems. EPRI EA-4020. Electric Power Research Institute, Palo Alto, CA. July 1985.

10 Fritzsche, A.F. The health risks of energy production. Risk Analysis 9:565-577 (1989).

1 UNEP. The Environmental Impacts of Production and Use of Energy. Part IV: The Comparative Assessment of the Environmental Impacts of Energy Sources (3rd Draft). United Nations Environment Program, Nairobi, Kenya. January 1985. 


\section{APPENDICES}

\begin{tabular}{|c|c|c|c|c|}
\hline Study & Coal & Oil & Gas & Uranium \\
\hline $\begin{array}{l}\text { WASH-1224, } 1974 \\
\text { Hamilton, 1974 } \\
\text { Hittman, 1974 } \\
\text { Smith, et al., 1975 } \\
\text { Comar and Sagan, } 1976 \\
\text { OECD, 1976 } \\
\text { MITRE, 1977 } \\
\text { Morris, } 1977 \\
\text { WHO, 1978 } \\
\text { Inhaber, 1978 } \\
\text { IEA, 1979 } \\
\text { AMA, 1978 } \\
\text { UK, 1978 } \\
\text { Ramsay, 1978 } \\
\text { Schurr, et al., } 1979 \\
\text { Morris, et al., 1979 } \\
\text { Inhaber, 1980 } \\
\text { CEPN, 1979 } \\
\text { CONAES, 1980 }\end{array}$ & $\begin{array}{l}1.5 \\
0.46 \\
1.7 \\
2.4-7.5 \\
0.71-1.9 \\
1.4 \\
0.53-0.93 \\
2.3-6.6 \\
0.19-1.4 \\
0.72-4.3 \\
1.8 \\
0.48-1.5 \\
0.4-1.3 \\
0.77-0.80 \\
2.1\end{array}$ & $\begin{array}{l}0.21 \\
1.63 \\
0.11 \\
0.11-0.18 \\
0.2-1.8 \\
0.47\end{array}$ & $\begin{array}{l}0.11 \\
0.21 \\
0.086 \\
2.6-7.1 \\
0.76-0.37\end{array}$ & $\begin{array}{l}0.14 \\
0.35 \\
0.18 \\
0.14-0.31 \\
0.09-0.55 \\
0.69 \\
0.14-0.29 \\
0.55 \\
0.10-0.60 \\
\\
0.027-0.55 \\
0.25 \\
0.09-0.31 \\
0.08-0.27\end{array}$ \\
\hline
\end{tabular}




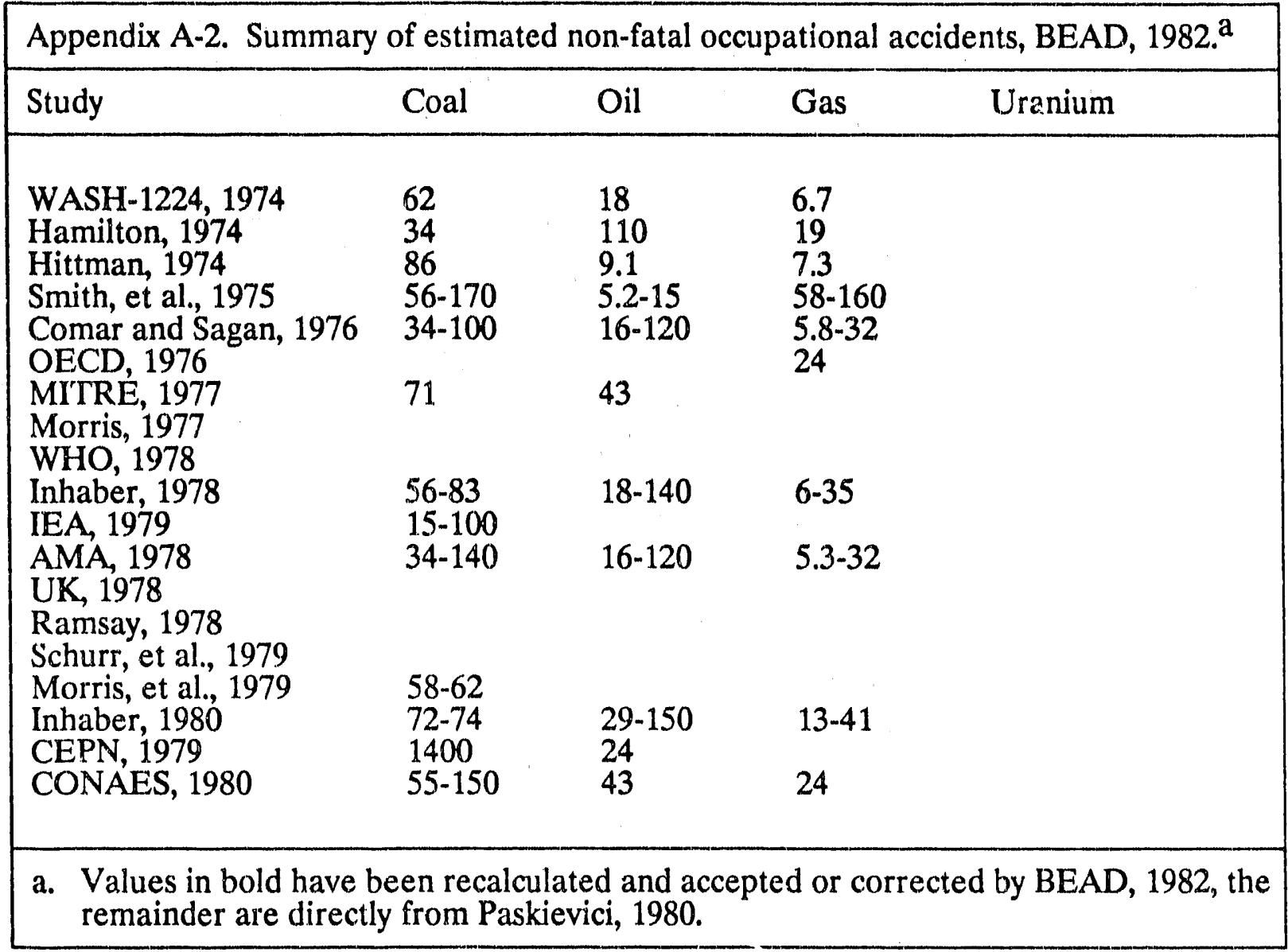




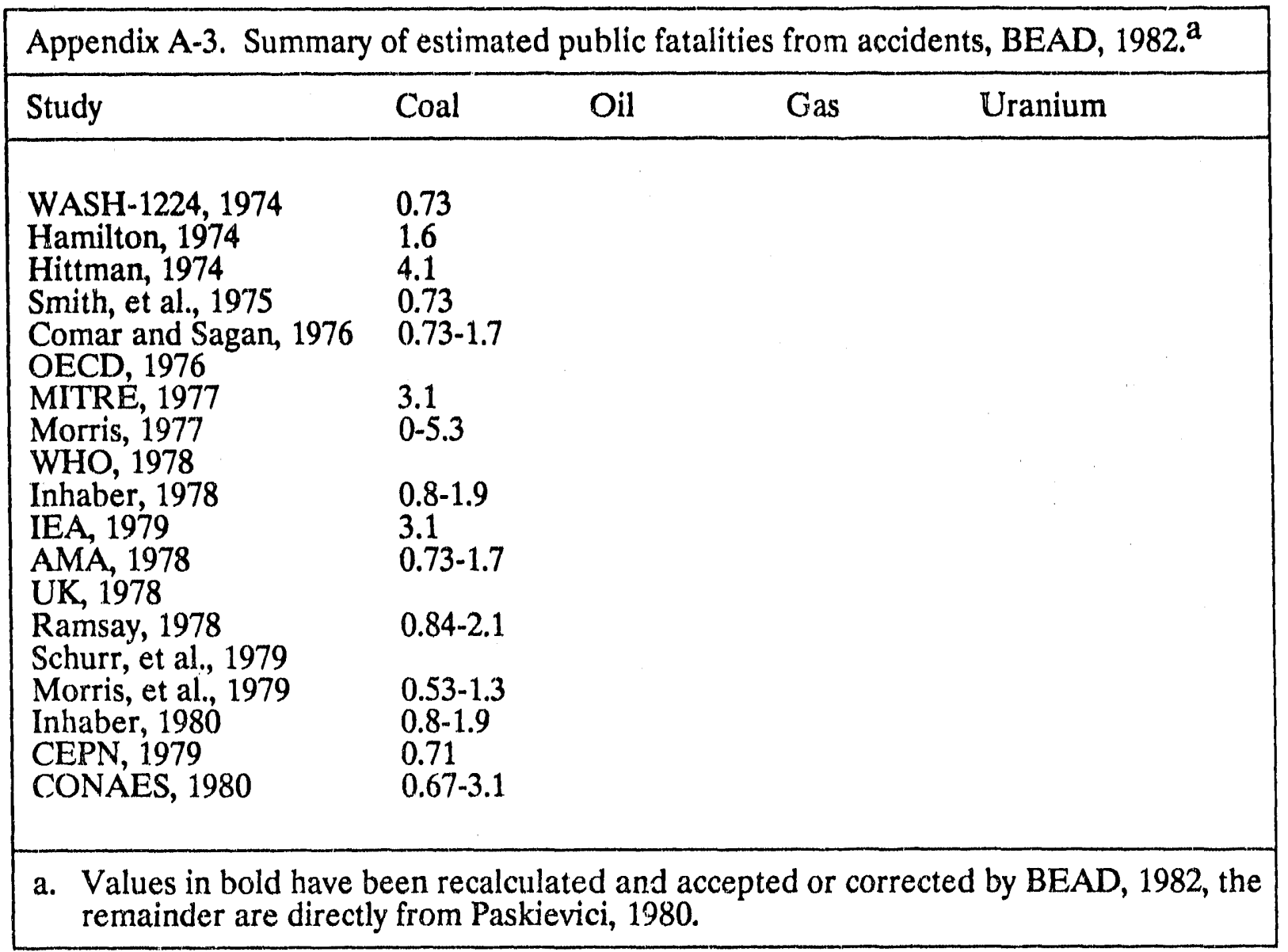




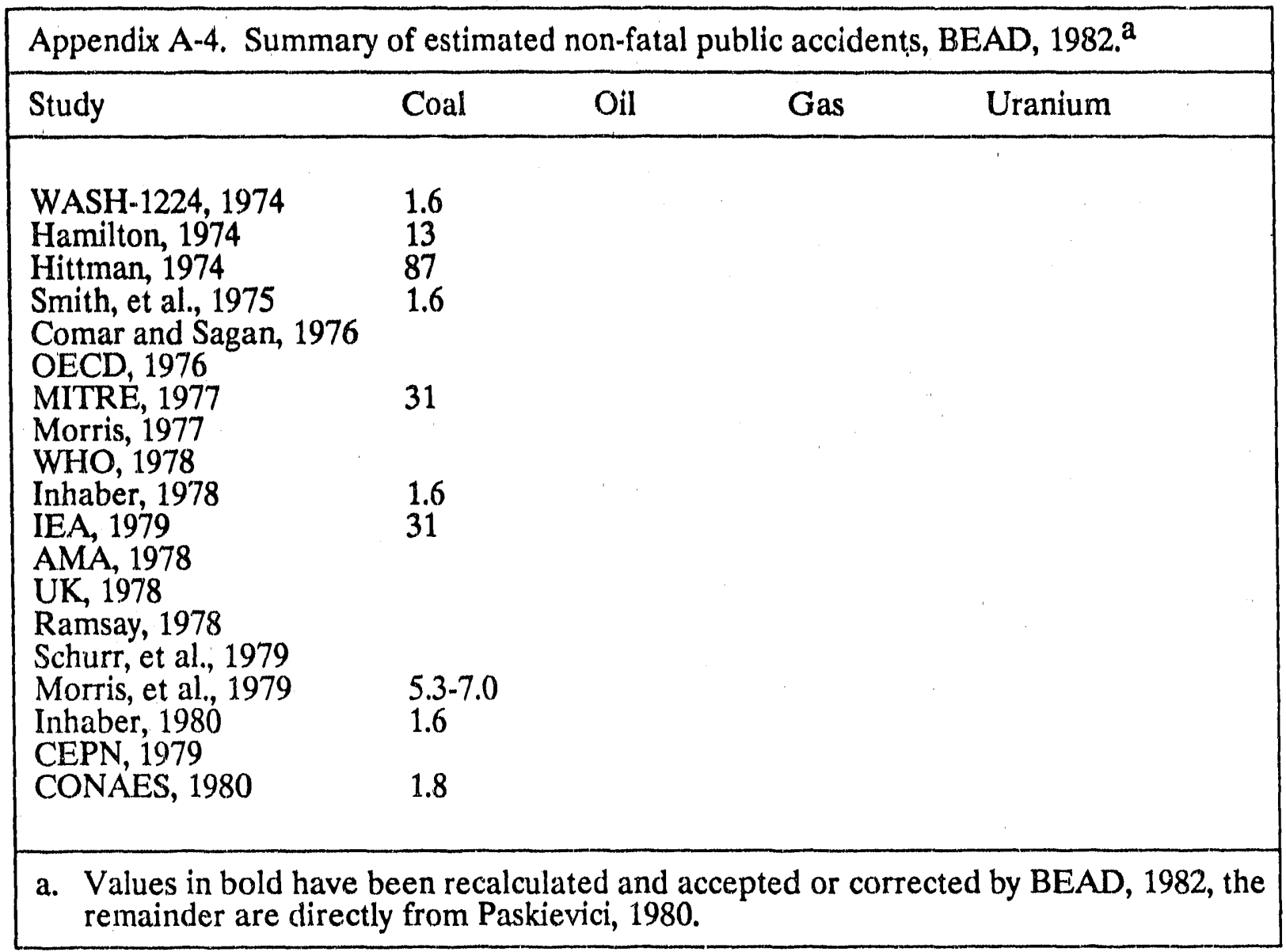




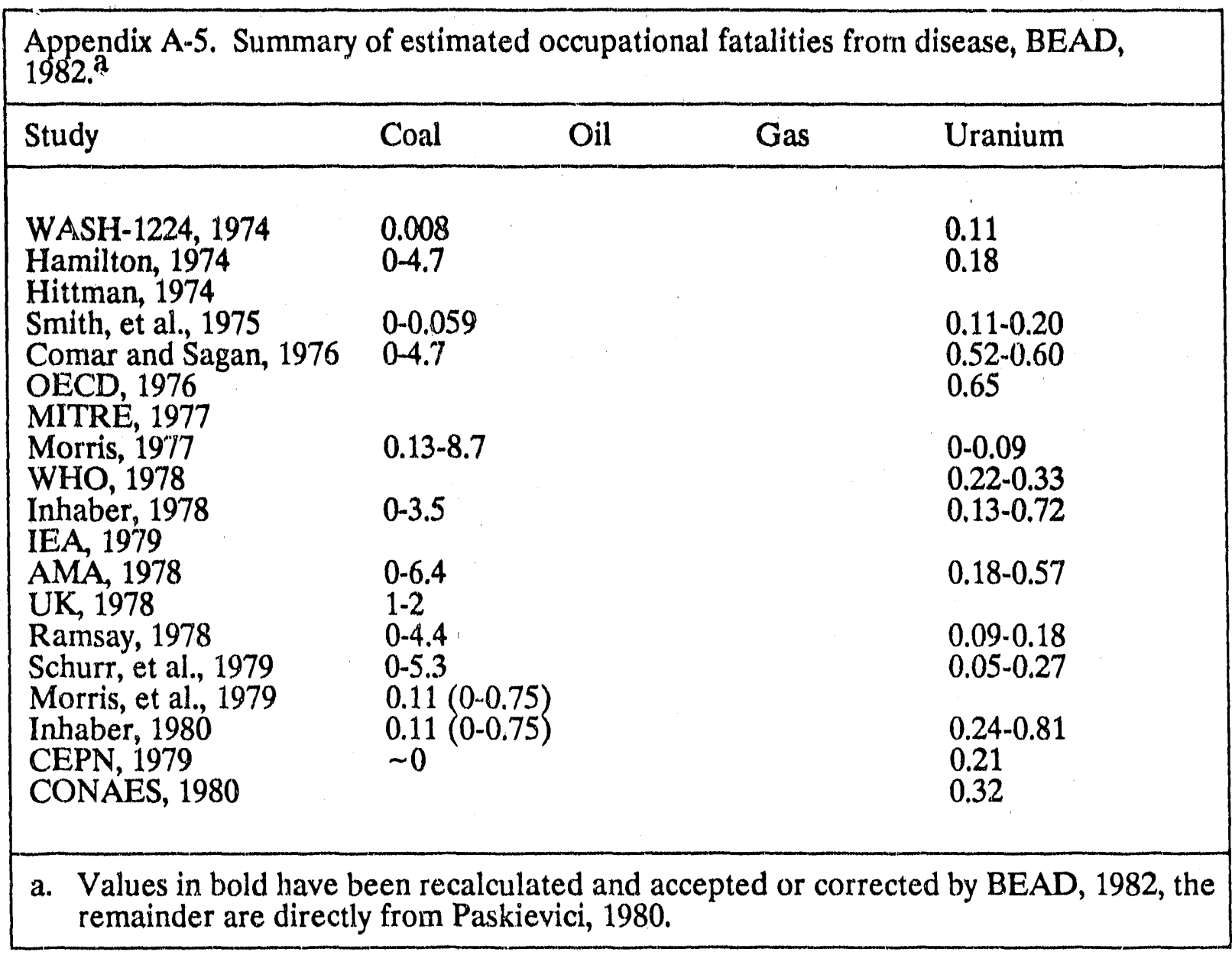




\begin{tabular}{|c|c|c|c|c|}
\hline Study & Coal & Oil & Gas & Uranium \\
\hline $\begin{array}{l}\text { WASH-1224, } 1974 \\
\text { Hamilton, 1974 } \\
\text { Hittman, 1974 } \\
\text { Smith, et al., 1975 } \\
\text { Comar and Sagan, } 1976 \\
\text { OECD, 1976 } \\
\text { MITRE, 1977 } \\
\text { Morris, } 1977 \\
\text { WHO, 1978 } \\
\text { Inhaber, 1978 } \\
\text { IEA, 1979 } \\
\text { AMA, 1978 } \\
\text { UK, 1978 } \\
\text { Ramsay, 1978 } \\
\text { Schurr, et al., } 1979 \\
\text { Morris, et al., } 1979 \\
\text { Inhaber, 1980 } \\
\text { CEPN, 1979 } \\
\text { CONAES, } 1980\end{array}$ & $\begin{array}{l}0.8 \\
13-60 \\
\\
0.55-0.82 \\
0.8-64\end{array}$ & & & 0.97 \\
\hline
\end{tabular}

a. Values in bold have been recalculated and accepted or corrected by BEAD, 1982, the remainder are directly from Paskievici, 1980. 


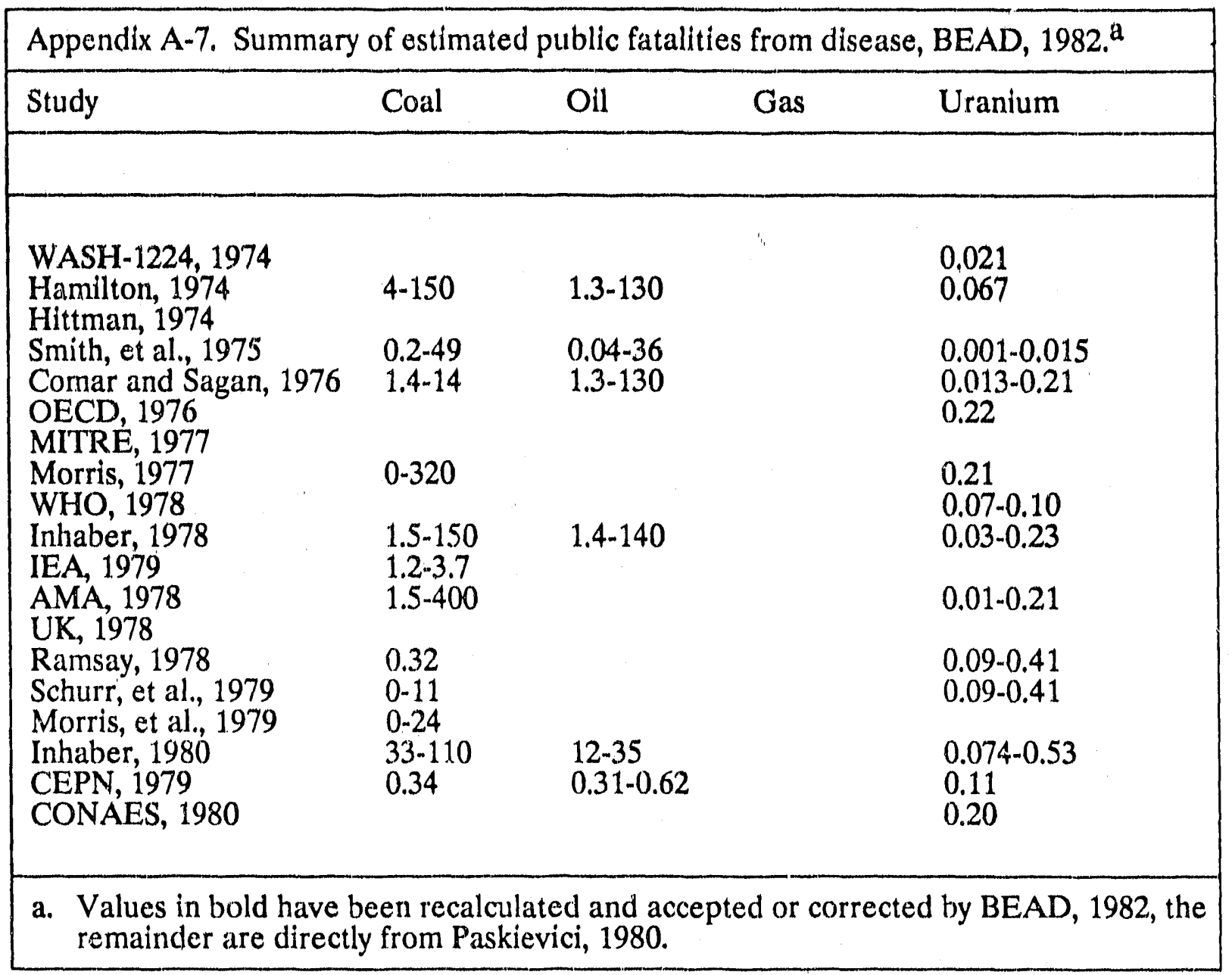




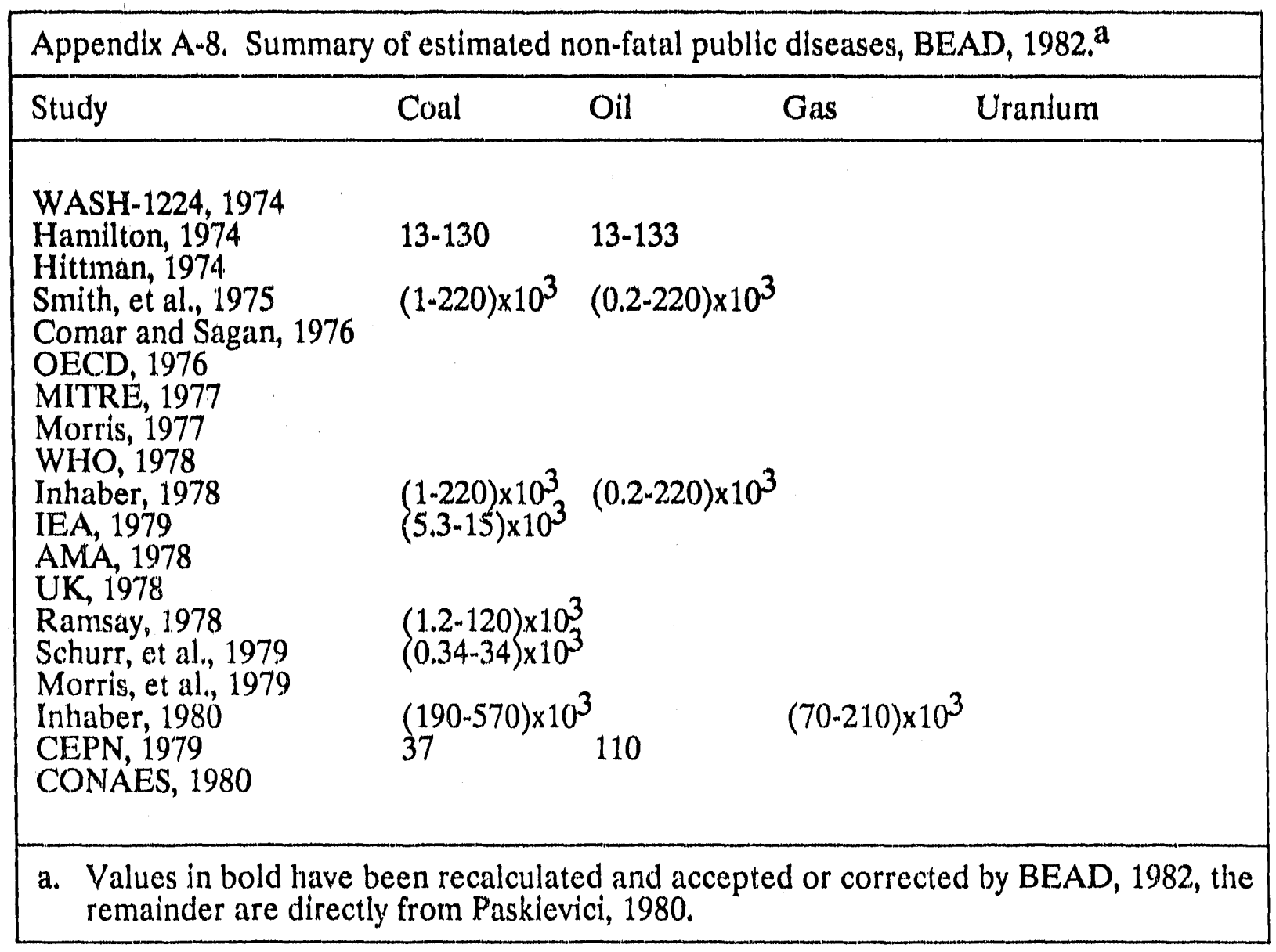




\begin{tabular}{|c|c|c|c|}
\hline \multicolumn{4}{|c|}{ Appendix B-1. Health risks of energy technologies, UNEP 1985 . $^{\mathrm{a}}$} \\
\hline \multirow[t]{2}{*}{ Technology } & \multirow{2}{*}{$\begin{array}{l}\text { Occupational } \\
\text { Deaths }\end{array}$} & \multicolumn{2}{|c|}{ Risks (per GWe-y) } \\
\hline & & $\begin{array}{l}\text { Injuries/ } \\
\text { diseases } \\
\text { (WDL) }\end{array}$ & $\begin{array}{l}\text { Public } \\
\text { Deaths }\end{array}$ \\
\hline $\begin{array}{l}\text { FUELS -.. ELECTRICIT } \\
\text { Coal }\end{array}$ & & & \\
\hline $\begin{array}{l}\text { Surface mining } \\
\text { Underground mining } \\
\text { Coal cleaning } \\
\text { Power plant }\end{array}$ & $\begin{array}{l}0.0016 \\
0.031 \\
0.00091 \\
0.00039-0.0057\end{array}$ & $\begin{array}{l}9.4 \\
80 . \\
2.4 \\
1.9-2.8\end{array}$ & 0.059 \\
\hline $\begin{array}{l}\text { Oil } \\
\text { Onshore wells } \\
\text { Offshore wells } \\
\text { Refinery } \\
\text { Power plant }\end{array}$ & $\begin{array}{l}0.0072 \\
0.0072 \\
7.8 \times 10^{-5} \\
0.00017 \times 0.00026\end{array}$ & $\begin{array}{l}13 . \\
13 . \\
21 . \\
0.32 \times 3.5\end{array}$ & 0.030 \\
\hline $\begin{array}{l}\text { Natural gas } \\
\text { Onshore and offshore } \\
\text { production } \\
\text { Purification } \\
\text { Power plant }\end{array}$ & $\begin{array}{l}0.0013=0.0021 \\
5.2 \times 10^{-6}=3.9 \times 10^{-5} \\
0.00011-0.00022\end{array}$ & $\begin{array}{l}4.7-5.0 \\
0.011-0.032 \\
0.25-3.5\end{array}$ & $1.3 \times 10^{-5}$ \\
\hline $\begin{array}{l}\text { Gasification of low } \\
\text { calorie coal } \\
\text { Surface mining } \\
\text { Underground mining } \\
\text { Coal cleaning } \\
\text { Gasifying power } \\
\text { plant }\end{array}$ & $\begin{array}{l}0.0019 \\
0.030 \\
0.0014 \\
0.0017\end{array}$ & $\begin{array}{l}11 . \\
94 . \\
4.8 \\
6.8\end{array}$ & $1.3 \times 10^{-5}-0.26 \mathrm{~d}$ \\
\hline $\begin{array}{l}\text { Gasification of high } \\
\text { calorie coal } \\
\text { Surface mining } \\
\text { Underground mining } \\
\text { Coal processing } \\
\text { Power plant }\end{array}$ & $\begin{array}{l}0.0051 \\
0.0796 \\
0.0048 \\
0.00011 \cdot 0.0017\end{array}$ & $\begin{array}{l}30 \\
110-260 \\
2.3 \\
0.98-3.6\end{array}$ & $1.3 \times 10^{-5}$ \\
\hline $\begin{array}{l}\text { Indirect liquefaction } \\
\text { of coal } \\
\text { Surface mining } \\
\text { Underground mining } \\
\text { Fuel processing } \\
\text { Power plant }\end{array}$ & $\begin{array}{l}0.13 \\
2.1 \\
0.0017\end{array}$ & $\begin{array}{l}790 \\
6700\end{array}$ & 0.030 \\
\hline
\end{tabular}




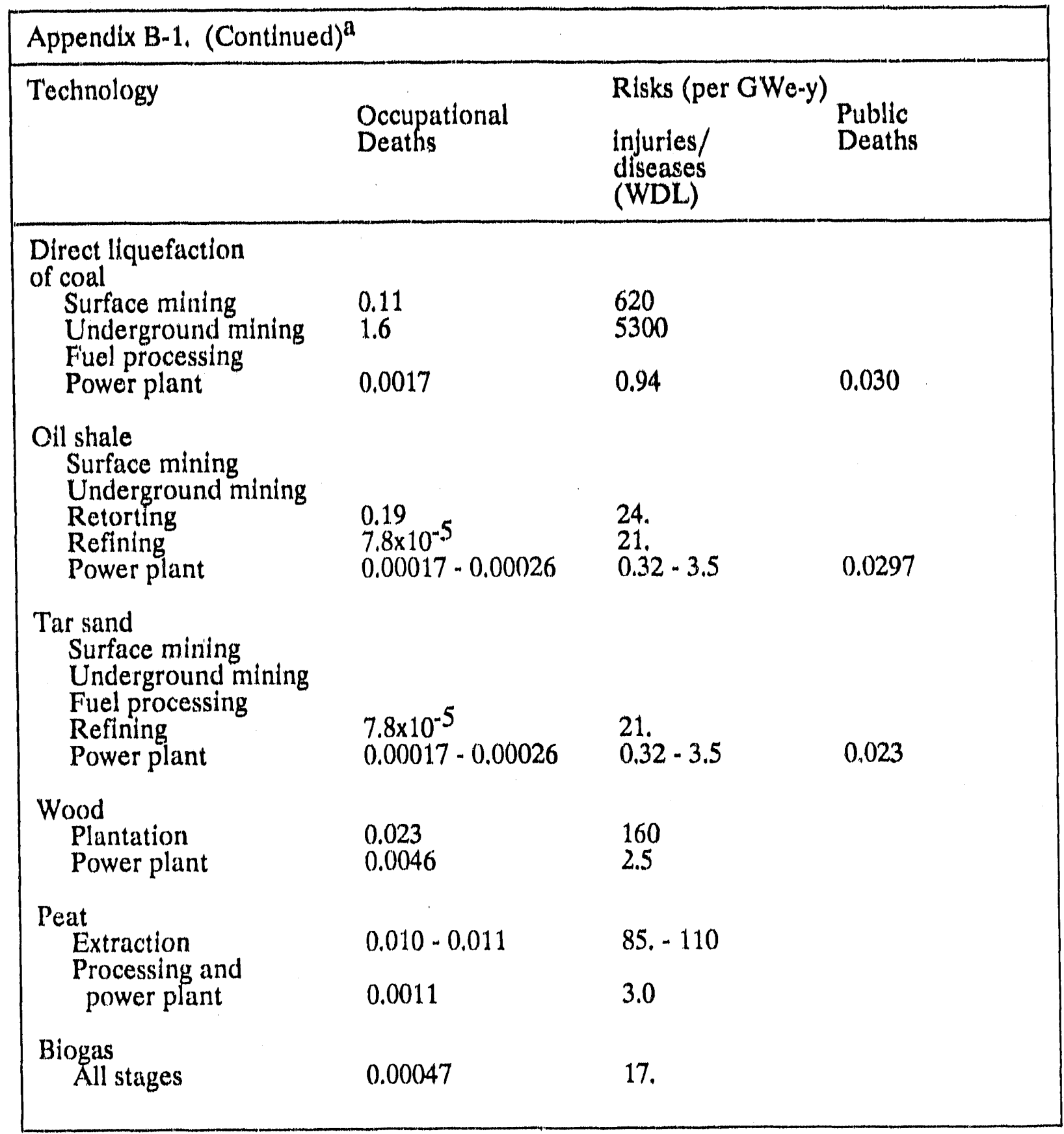




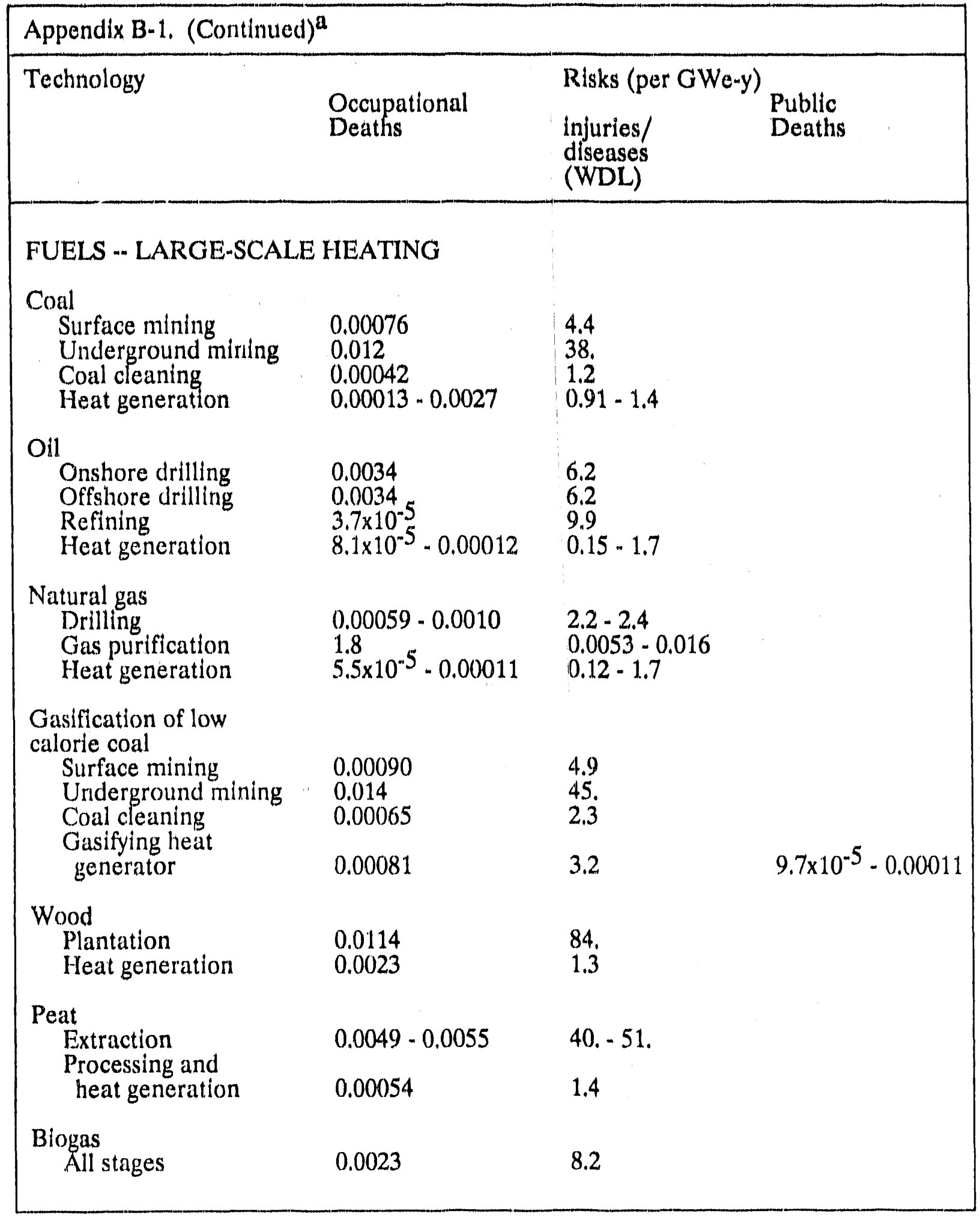




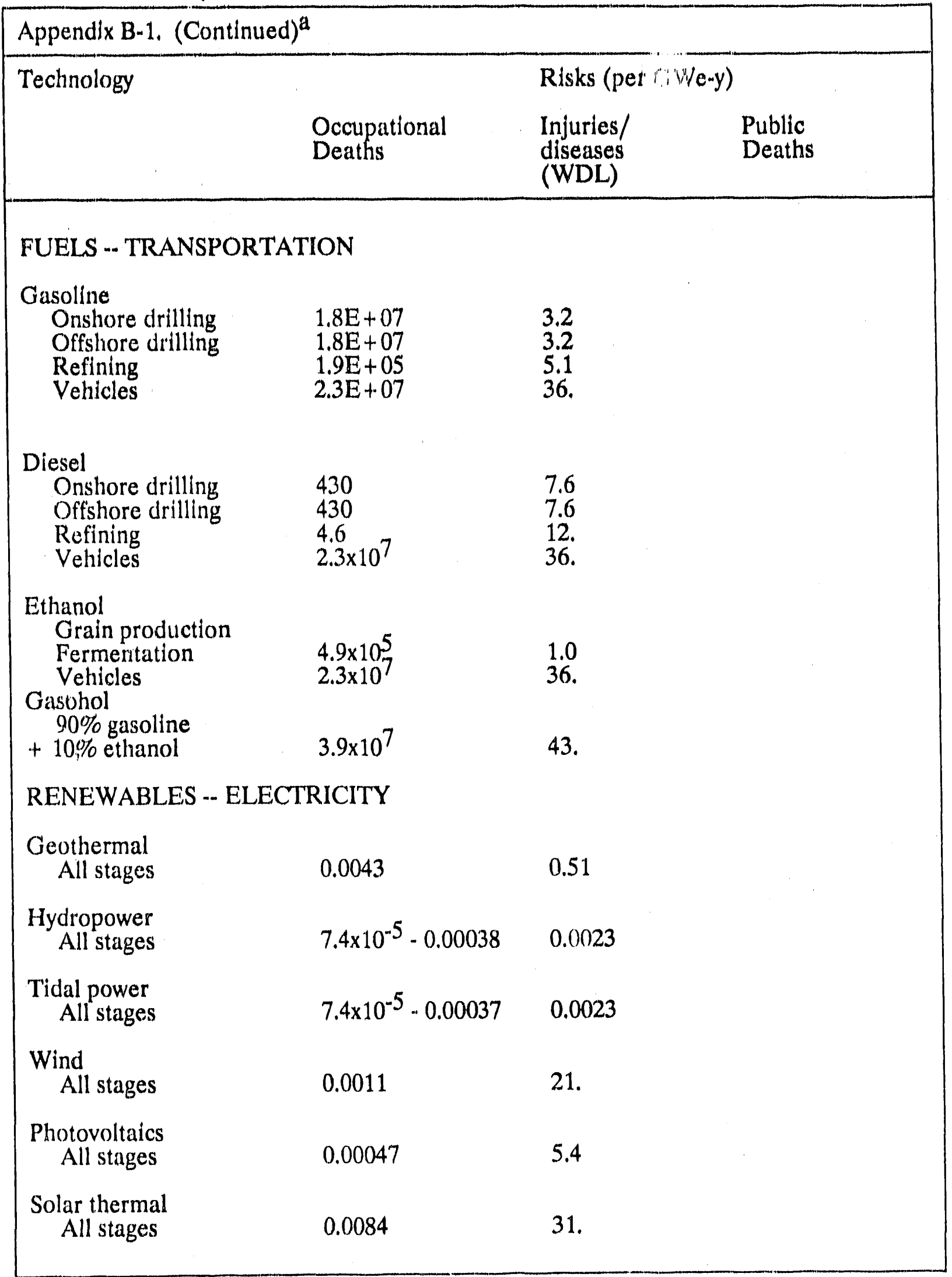




\begin{tabular}{|c|c|c|c|}
\hline \multicolumn{4}{|c|}{ Appendix B-1. (Continued) ${ }^{\mathrm{a}}$} \\
\hline \multirow[t]{2}{*}{ Technology } & \multirow[b]{2}{*}{$\begin{array}{l}\text { Occupational } \\
\text { Deaths }\end{array}$} & \multicolumn{2}{|c|}{ Risks (per GWe-y) } \\
\hline & & $\begin{array}{l}\text { Injuries/ } \\
\text { diseases } \\
\text { (WDL) }\end{array}$ & $\begin{array}{l}\text { Public } \\
\text { Deaths }\end{array}$ \\
\hline \multicolumn{4}{|c|}{ RENEWABLES -- LARGE-SCALE HEATING } \\
\hline $\begin{array}{l}\text { Geothermal } \\
\text { All stages }\end{array}$ & $9.4 \times 10^{-4}$ & 0.11 & \\
\hline $\begin{array}{l}\text { Solar thermal } \\
\text { All stages }\end{array}$ & $2.3 \times 10^{-3}$ & 8.3 & \\
\hline \multicolumn{4}{|c|}{ NUCLEAR -- ELECTRICITY } \\
\hline $\begin{array}{l}\text { LWR Fission } \\
\text { Surface mining } \\
\text { Accidents } \\
\text { Radiation }\end{array}$ & $\begin{array}{l}6.5 \times 10^{-4} \\
3.9 \times 10^{-4}-1.3 \times 10^{-2}\end{array}$ & 1.21 & $2.6 \times 10^{-4}$ \\
\hline $\begin{array}{l}\text { Underground mining } \\
\text { Accidents } \\
\text { Radiation }\end{array}$ & $\begin{array}{l}2.2 \times 10^{-3} \\
3.9 \times 10^{-4}-1.3 \times 10^{-3}\end{array}$ & 1.9 & $2.6 \times 10^{-4}$ \\
\hline $\begin{array}{l}\text { Milling } \\
\text { Accidents } \\
\text { Radiation }\end{array}$ & $\begin{array}{l}1.7 \times 10^{-4} \\
4.7 \times 10^{-4}\end{array}$ & 0.89 & $6.5 \times 10^{-5}$ \\
\hline $\begin{array}{l}\text { Conversion } \\
\text { Accidents } \\
\text { Radiation }\end{array}$ & $\begin{array}{l}5.5 \times 10^{-6} \\
5.3 \times 10^{-6}\end{array}$ & 0.31 & $1.3 \times 10^{-5}$ \\
\hline $\begin{array}{l}\text { Enrichment } \\
\text { Accidents } \\
\text { Radiation }\end{array}$ & $\begin{array}{l}7.8 \times 10^{-6} \\
6.8 \times 10^{-6}\end{array}$ & 4.3 & $8.0 \times 10^{-8}$ \\
\hline $\begin{array}{l}\text { Fabrication } \\
\text { Accidents } \\
\text { Radiation }\end{array}$ & $\begin{array}{l}8.6 \times 10^{-5} \\
1.3 \times 10^{-4}\end{array}$ & 0.82 & \\
\hline $\begin{array}{l}\text { Power plant } \\
\text { Accidents }\end{array}$ & & & \\
\hline $\begin{array}{l}\text { Accidents } \\
\text { Radiation } \\
\text { Catastrophe }\end{array}$ & $\begin{array}{l}1.7 \times 10^{-4} \\
1.7 \times 10^{-3}\end{array}$ & $\begin{array}{l}0.28 \\
0.034\end{array}$ & $\begin{array}{l}2.3 \times 10^{-4} \\
1.3 \times 10^{-3}\end{array}$ \\
\hline $\begin{array}{l}\text { Waste management } \\
\text { Radiation }\end{array}$ & $6.1 \times 10^{-6}$ & $0.00011^{b}$ & $1.0 \times 10^{-4}$ \\
\hline
\end{tabular}




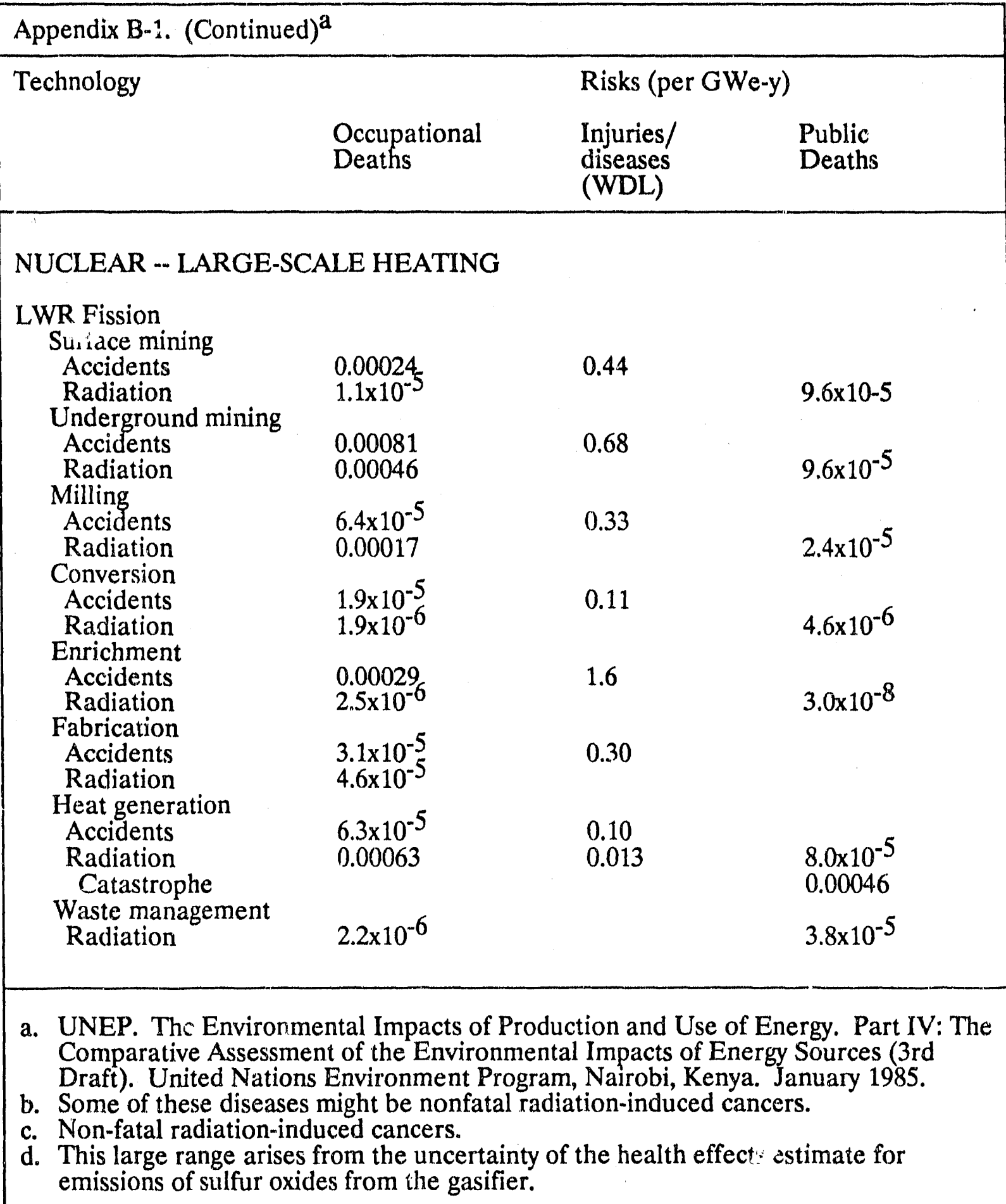



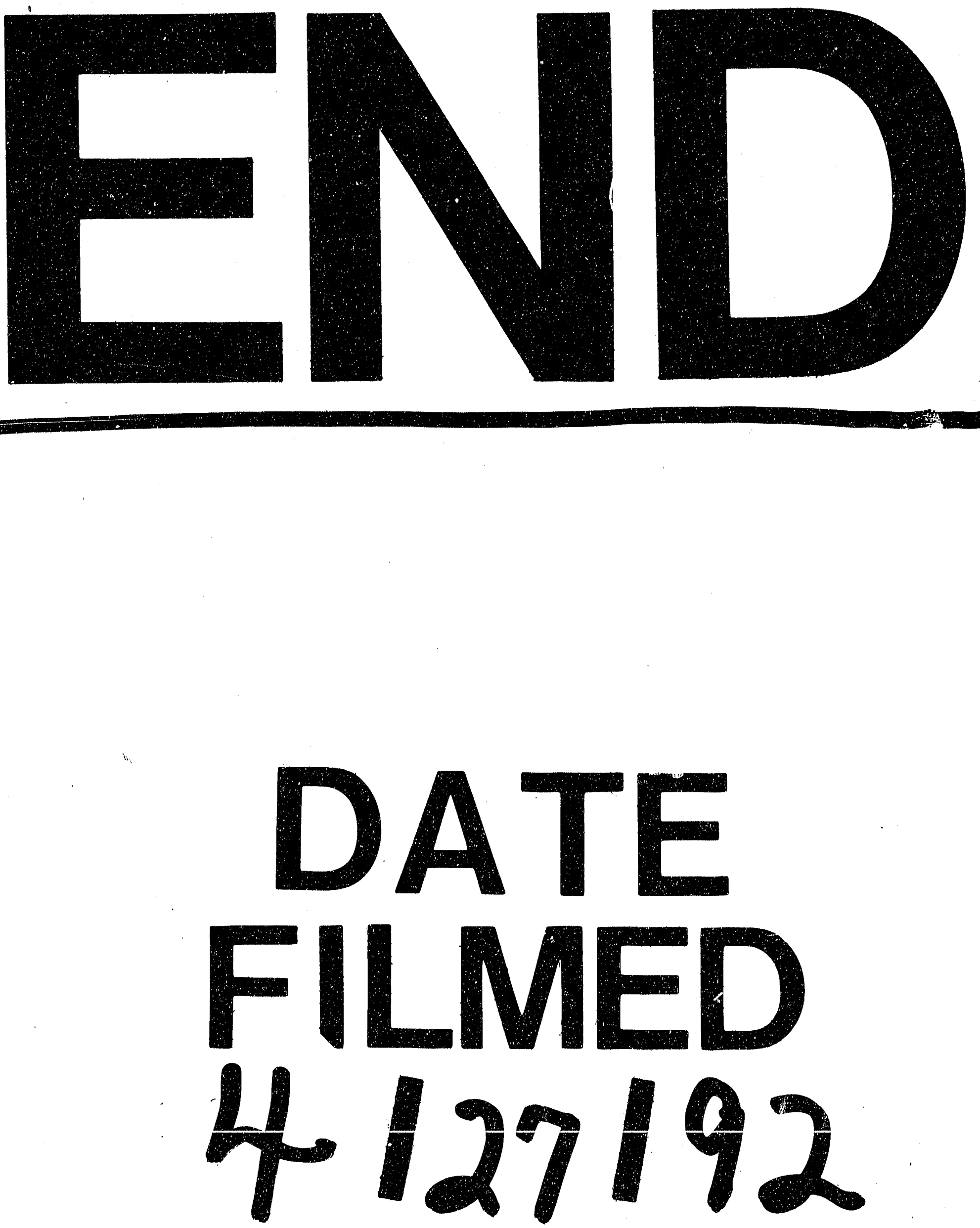
